\title{
СМЕРТНОСТЬ ОТ ВНЕШНИХ ПРИЧИН В РОССИИ
}

\section{ЗА ПОЛВЕКА*}

\author{
ЕКАТЕРИНА КВАША, ТАТЬЯНА ХАРЬКОВА, ВАЛЕРИЙ ЮМАГУЗИН
}

\begin{abstract}
В статье рассматривается долговременная, с 1956 г., динамика смертности от внешних причин смерти в России. Показано длительное отставание России от развитых стран как по уровню смертности от внешних причин, который и сейчас продолжсает оставаться высоким, так и по структуре смертности, архаизм которой проявляется в большом вкладе убийств, алкогольньх отравлений и повреждений с неопределенными намерениями.
\end{abstract}

На основе таблиц смертности в работе рассчитаны избыточные числа смертей (dx) от основных групп внешних причин в России по сравнению с западноевропейскими странами, показано, что в России наибольшие избыточные потери связаны со смертностью от отравлений у обоих полов, самоубийств у мужчин и убийств у женщин.

Смертность от внешних причин наряду со смертностью от болезней системь кровообращения оказывает существенное влияние на ожидаемую продолжительность жизни. В иелом за 1956-2012 г2. рост смертности от внешних причин в возрасте 15-64 года сократил ожидаемую продолжительность жизни у мужчин на 2,6 года и у женщин на 0,7 года.

Наблюдаемое с 2003 г. снижение смертности от внешних причин позволило уменьшить разрыв с развитыми странами и приблизиться к достигнутым в России уровням смертности середины 1960х и 1980-х годов, однако, учитывая колебательный характер изменений смертности от внешних причин, преждевременно судить, станет ли нынешнее снижение смертности устойчивым трендом.

Ключевые слова: смертность в России, внешние причины смерти, избыточная смертность, продолжительность жизни.

\section{СМЕРТНОСТЬ ОТ ВНЕШНИХ ПРИЧИН НА ФОНЕ ОБЩЕЙ СМЕРТНОСТИ}

Регулярная статистика смертности от внешних причин в России имеется с 1956 г. [Богоявленский 2001]. Она стала доступна исследователям в начале 1990-х годов, но тогда ее использование было затруднено нарушением сопоставимости долговременных непрерывных рядов при переходе от одного пересмотра Международной классификации причин смерти к другому. На протяжении многих лет группой французских и российских демографов велась совместная кропотливая работа по реклассификации данных из одной номенклатуры причин смерти в другую, с тем чтобы обеспечить сопоставимость непрерывных рядов данных.

\footnotetext{
ЕКАТЕРИНА АЛЕКСАНДРОВНА КВАША, ИНСТИТУТ ДЕМОГРАФИИ НАЦИОНАЛЬНОГО ИССЛЕДОВАТЕЛЬСКОГО УНИВЕРСИТЕТА «ВЫСШАЯ ШКОЛА ЭКОНОМИКИ». РОССИЯ. E-mail: ekvasha@hse.ru.

ТАТЬЯНА ЛЕОНИДОВНА ХАРЬКОВА, ИНСТИТУТ ДЕМОГРАФИИ НАЦИОНАЛЬНОГО ИССЛЕДОВАТЕЛЬСКОГО УНИВЕРСИТЕТА «ВЫСШАЯ ШКОЛА ЭКОНОМИКИ». РОССИЯ. Е-mail: tkharkova@ hse.ru. ВАЛЕРИЙ ВАЛЕРЬЕВИЧ ЮМАГУЗИН, ИНСТИТУТ ДЕМОГРАФИИ НАЦИОНАЛЬНОГО ИССЛЕДОВАТЕЛЬСКОГО УНИВЕРСИТЕТА «ВЫСШАЯ ШКОЛА ЭКОНОМИКИ». РОССИЯ. E-mail: vyumaguzin@hse.ru.

СТАТЬЯ ПОСТУПИЛА В РЕДАКЦИЮ В ОКТЯБРЕ 2014 Г.

* В СТАТЬЕ ИСПОЛЬЗОВАНЫ РЕЗУЛЬТАТЫ, ПОЛУЧЕННЫЕ В ХОДЕ ИССЛЕДОВАНИЯ ПО ПРОЕКТУ № О5-ОО29 «ВНЕШНИЕ ПРИЧИНЫ СМЕРТИ В СИСТЕМЕ ПРИОРИТЕТОВ БОРЬБЫ ЗА УВЕЛИЧЕНИЕ ПРОДОЛЖИТЕЛЬНОСТИ ЖИЗНИ В РОССИИ» В РАМКАХ ПРОГРАММЫ «НАУЧНЫЙ ФОНД НИУ ВШЭ».
} 
Первые результаты этой работы для России были опубликованы в 1996 г. и относятся к периоду 1965-1994 гг. [Милле и др. 1996]. Ряд содержит 175 сопоставимых во времени причин смерти в кодировке действовавшей с 1988 г. советской номенклатуры. Несколько лет спустя тем же авторским коллективом, к которому присоединился Е.М. Андреев, работа была продолжена [Meslé et al. 2003], и в настоящее время имеется непрерывная серия данных начиная с 1959 г. [РосБРиС 2014]. Будучи дополнены официальными данными Росстата за 1956-1958 гг. и с конца 1990-х годов, эти данные создают надежную основу для анализа смертности от внешних причин смерти за более чем полувековой период. Представленный ниже анализ в значительной степени опирается на эти данные.

Использовав публиковавшиеся ранее или имевшиеся в архивах данные за дореволюционный период, Д.Д. Богоявленский восстановил непрерывный ряд показателей насильственной смертности для 50 губерний Европейской России за 1870-1914 гг. Объединение этих данных с общероссийскими, начинающимися с 1956 г., на одном графике не вполне корректно, но все же дает некоторое, пусть и не совсем точное, представление о направлении динамики смертности от внешних причин в России почти за полтора столетия (рисунок 1).

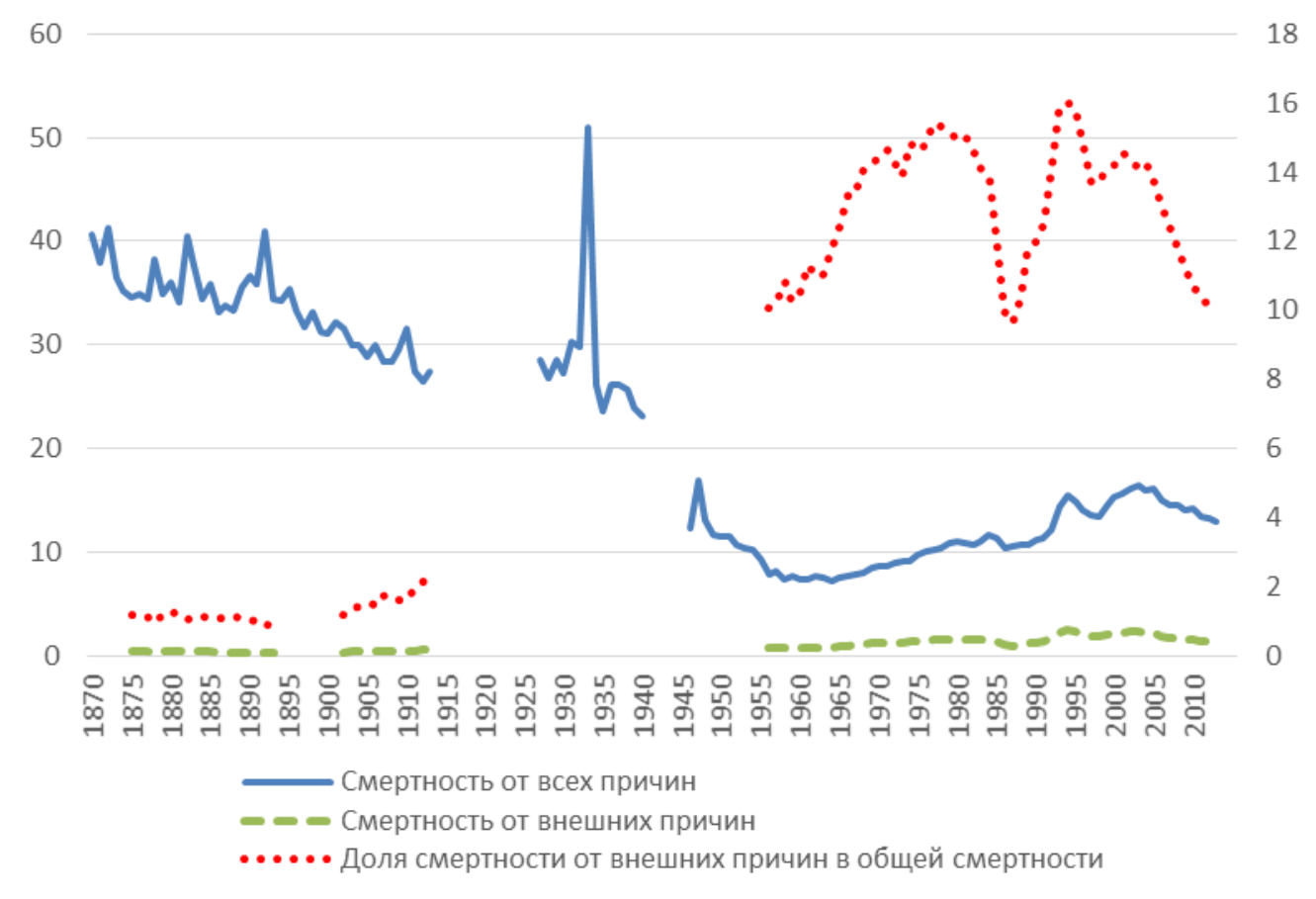

\section{Рисунок 1. Общий коэффициент смертности от всех причин и от внешних причин, \%, и доля смертности от внешних причин в общей смертности (правая шкала, \%) в Российской Империи - РСФСР - России, 1870-2012}

Источник: Рассчитано по [Богоявленский 2001; Росстат 2013].

Комментируя свой график, Д.Д. Богоявленский обращает внимание на неизменно растущую роль этого вида смертности. «В то время как общий коэффициент смертности в России на протяжении ста лет постепенно и с перерывами снижался, коэффициент смертности от внешних причин непрерывно рос, и этот рост продолжался и тогда, когда стал увеличиваться и общий коэффициент. Более того, именно рост насильственной 
смертности внес очень большой вклад в общее повышение смертности в России в последней трети XX века» [Богоявленский 2001].

За весь период с 1956 по 2013 г., за который имеются непрерывные данные, от этого класса причин в России умерло 12,1 млн человек (или свыше 13\% всех умерших). С 1956 г. до середины 1980-х годов число смертей от внешних причин устойчиво росло, затем оно снизилось на короткое время в период антиалкогольной кампании и «перестройки», после чего снова возобновило рост, достигнув исторического максимума в 1994 г. (рисунок 2).

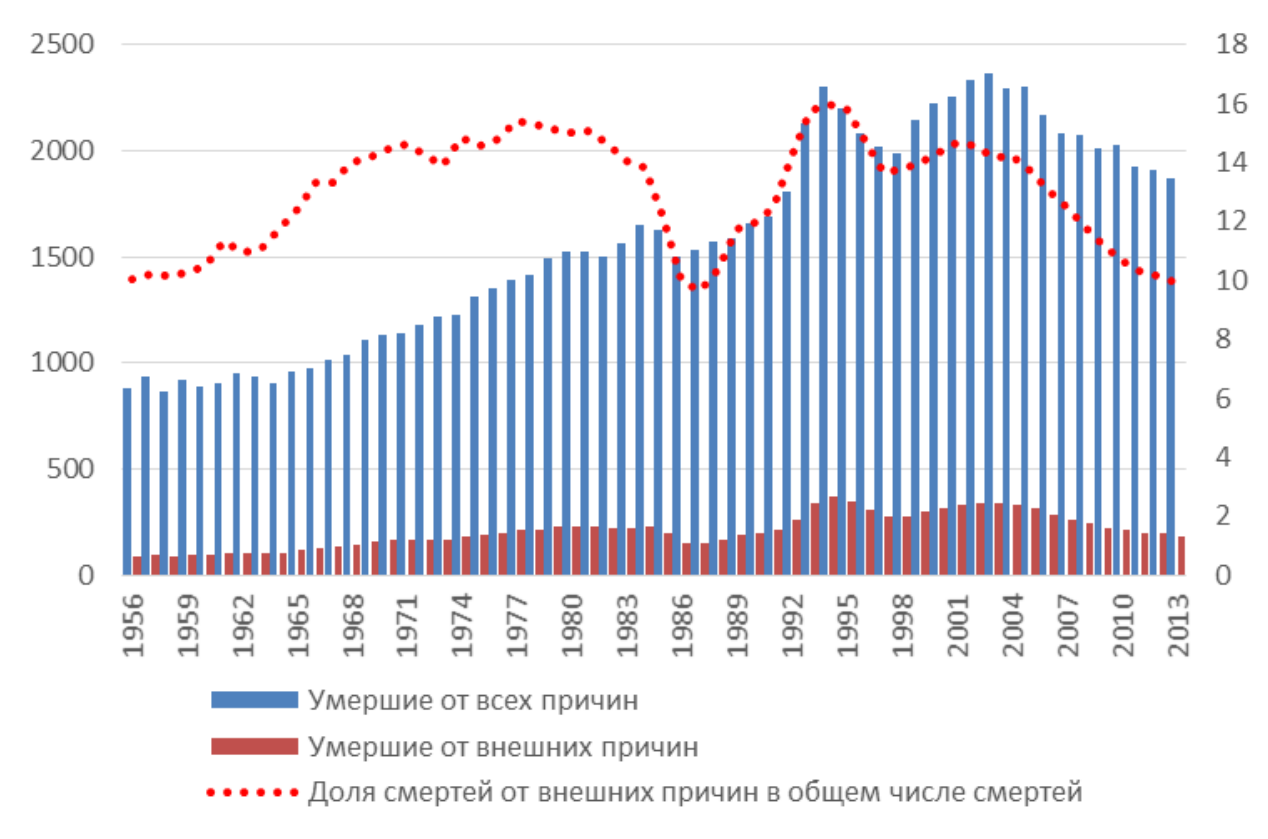

Рисунок 2. Число умерших от всех и от внешних причин, тыс., и доля смертей от внешних причин в общем числе смертей (правая шкала, \%) в России, 1956-2013

Источник: Рассчитано по [РосБРиС 2014].

Затем последовало снижение, сменившееся после 1998 г. новым подъемом, достигшим пика в 2003 г. Этот подъем оказался временным, после 2003 г. возобновилось снижение, идущее с небольшими колебаниями до сих пор. В 2011 г. число смертей от внешних причин впервые после 1990 г. опустилось ниже 200 тыс., а в 2012 г. - ниже уровня 1998 г.

Как следует из рисунка 2, вместе со снижением числа смертей от внешних причин снижается и их доля в общем числе смертей, оставаясь все же очень высокой. В стране, где вклад внешних причин в общую смертность некогда составлял 1-2\%, после 1956 г. он несколько раз опускался, в лучшем случае приближаясь к 10\%, но нередко поднимался до 15\% и даже выше. После пика 1994 г., когда доля смертей от внешних причин достигла максимума (16\%), она сократилась до 10,2\% в 2012 г. и до 9,9\% в 2013 г. Но в большинстве европейских стран эта доля значительно ниже (рисунок 3). В США, стране с населением в 2,2 раза большим, чем в России, в 2012 г. внешние причины унесли меньше жизней (190 тыс. [NCHS 2014] против 194 тыс. в России). 


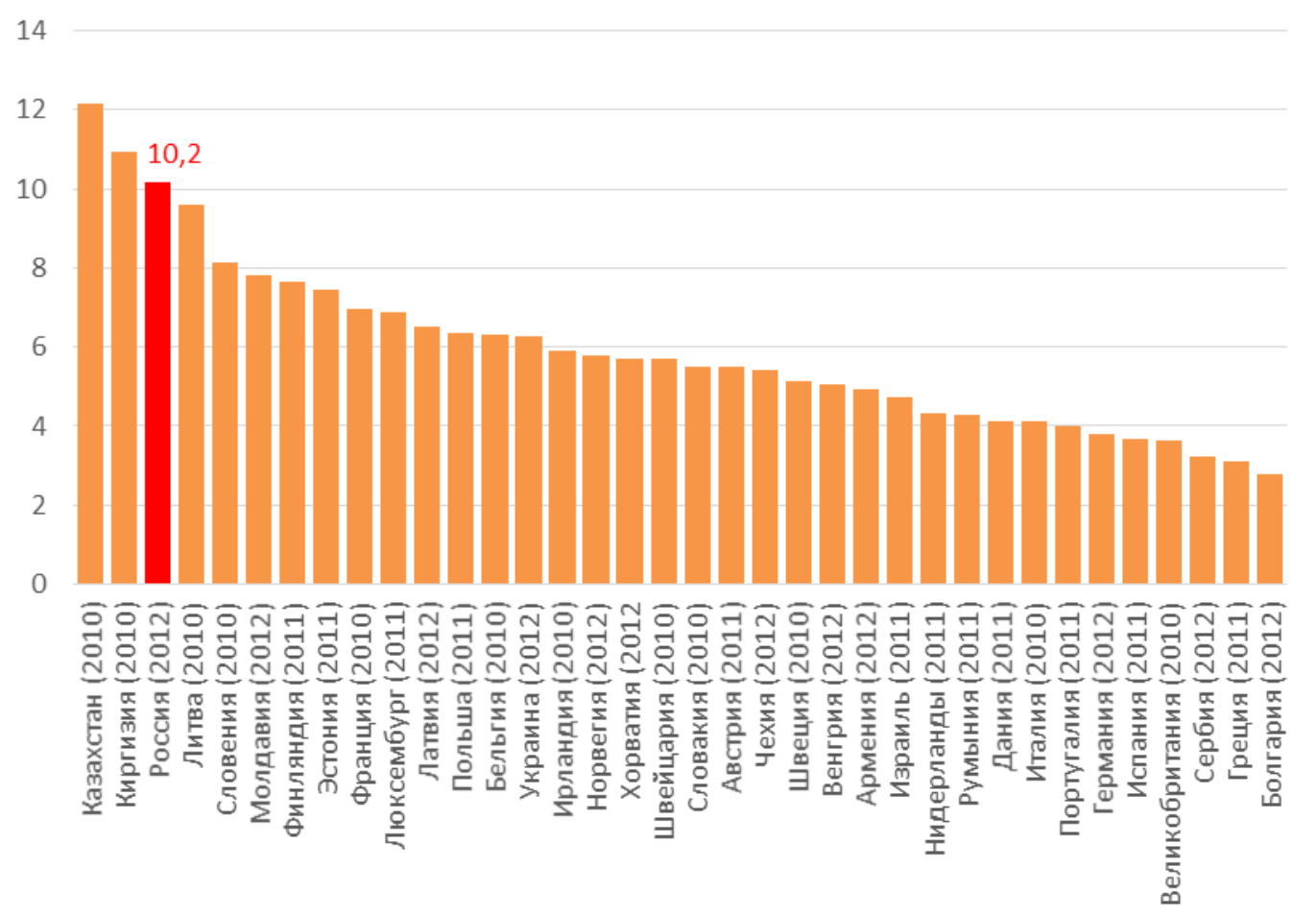

Рисунок 3. Доля умерших от внешних причин в общем числе умерших в России и некоторых странах мира, 2010-2012, \%

Источник: Рассчитано по [Росстат 2013; WHO DMDB 2014].

На огромное отставание России указывает и стандартизованный коэффициент смертности от внешних причин. Даже в начале 1970-х годов, когда разрыв был меньшим, чем сейчас, этот коэффициент у мужчин в России был примерно в два-три раза выше, чем на Западе, несколько меньшим, но тоже значительным, было превышение и у женщин. Дальнейшее же снижение смертности от внешних причин в западных странах и одновременно ее рост в России резко увеличили разрыв: в отдельные годы этот показатель превосходил типичные западные уровни для мужчин в 7-8 раз, а для женщин в 4-5 раз. В последние годы наметилось некоторое сближение, но очень большие различия сохраняются (рисунок 4). 
Мужчины

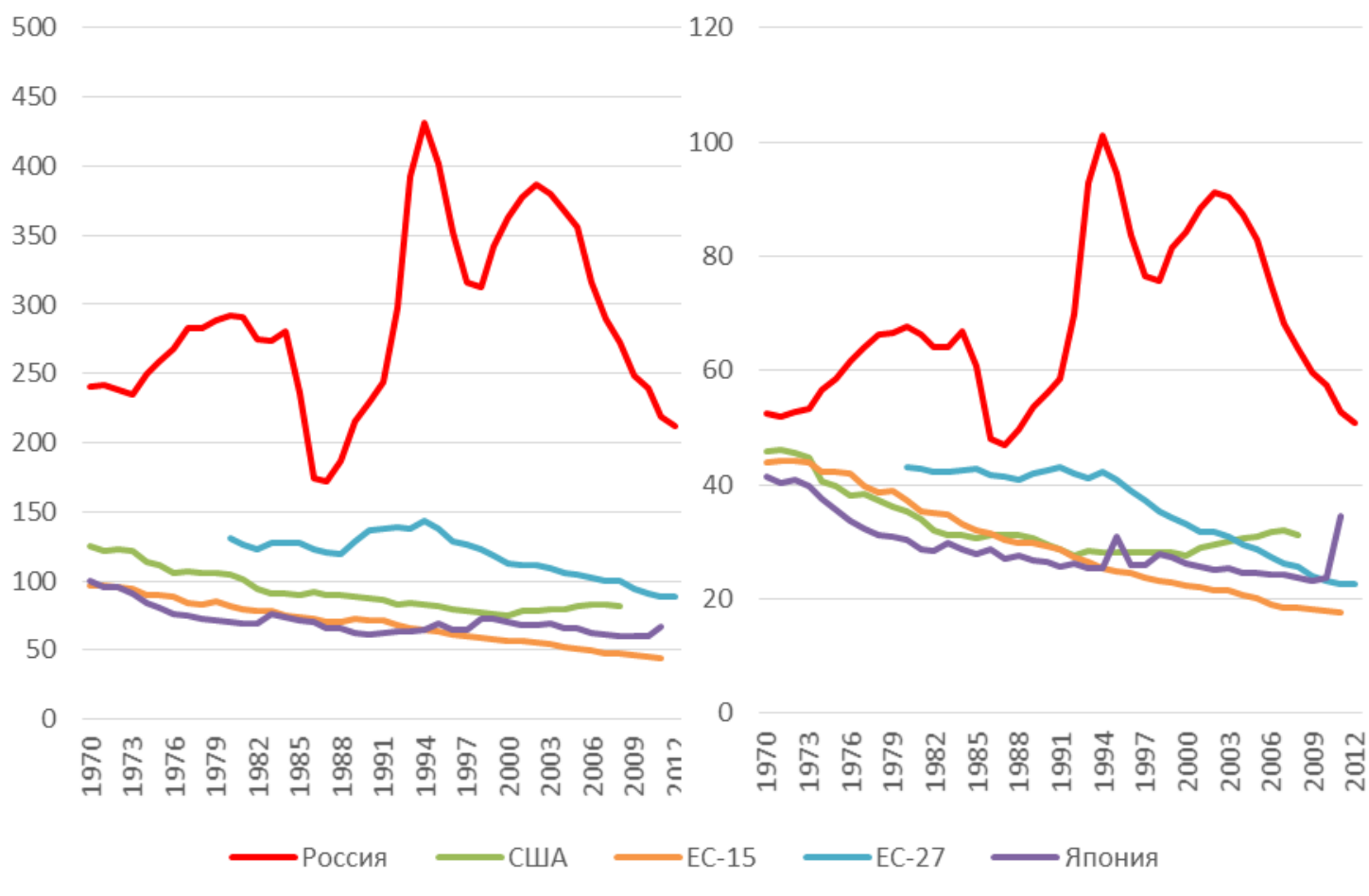

Рисунок 4. Стандартизованный коэффициент смертности от внешних причин в России, странах ЕC-15ํㅡ и Е-27², США и Японии, 1970-2012, на 100 тыс. населения соответствующего пола

Примечание: Использован Европейский стандарт ВОЗ.

Источник: Рассчитано по [Росстат 2013; WНО МDB 2014; WHO HFA 2014].

Как и абсолютное число смертей, стандартизованный коэффициент смертности от внешних причин в последнее время снижается, но пока, по сути, речь идет лишь о возврате к уровню начала 1990-х годов, тоже очень высокому, отрыв же от других развитых стран в ряде случаев даже увеличивается. Остается очень высоким и вклад смертности от внешних причин в формирование общего стандартизованного коэффициента смертности. Хотя в Европе есть страны, где, при более низкой, чем в России, общей смертности, относительный вклад внешних причин близок к российскому, это скорее исключение, чем правило. Если взять для сравнения среднюю величину как для «старых» стран Европейского союза (ЕС15), так и для всех стран ЕС-27, в России этот вклад почти вдвое выше (рисунок 5).

\footnotetext{
${ }^{1}$ Австрия, Бельгия, Великобритания, Германия, Греция, Дания, Италия, Ирландия, Испания, Люксембург, Нидерланды, Португалия, Финляндия, Франция, Швеция.

2 Те же страны плюс Болгария, Венгрия, Кипр, Латвия, Литва, Мальта, Польша, Словакия, Словения, Румыния, Чехия, Эстония.
} 


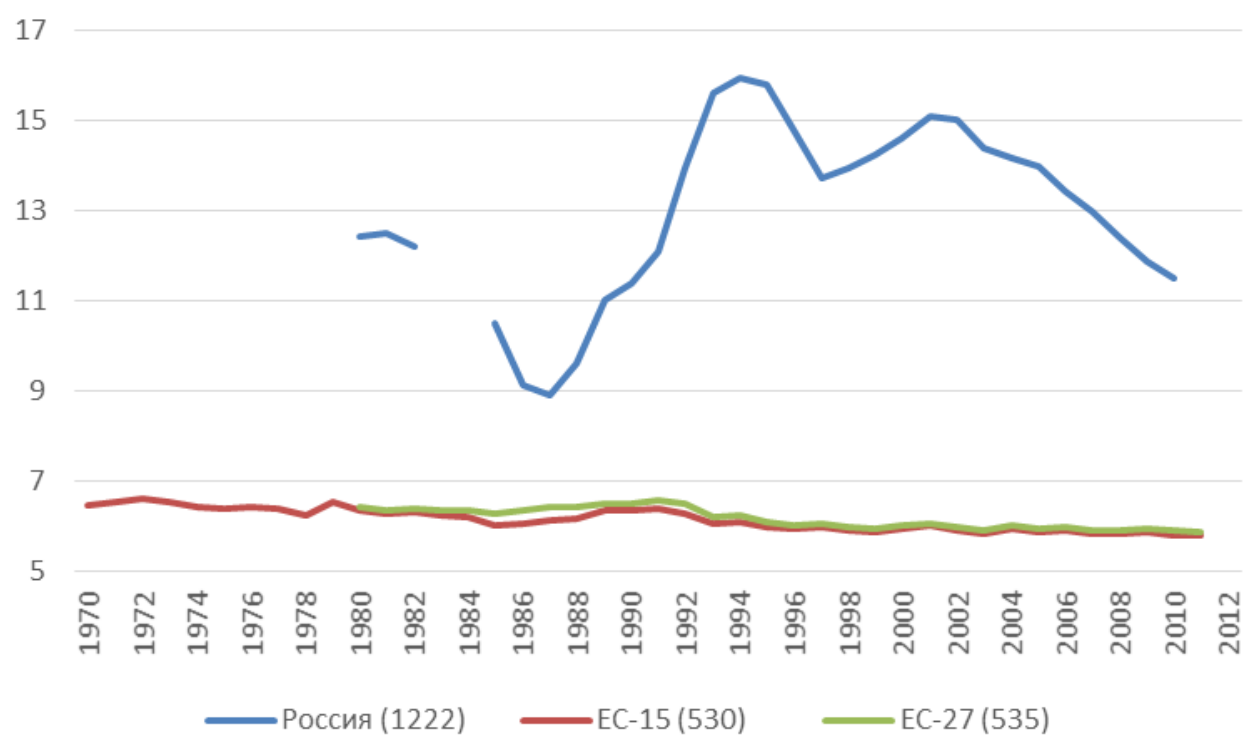

\section{Рисунок 5. Доля внешних причин в стандартизованном коэффициенте смертности от всех причин в России и странах ЕС, оба пола, 1970-2012, \%}

Примечание: В скобках-стандартизованный коэффициент смертности от всех причин в 2010 г., на 100 тыс. населения.

Источник: Рассчитано по [WНО НFА 2014; РосБРиС 2014].

В странах с низкой смертностью внешние причины обычно занимаю четвертое место среди причин смерти - после болезней системы кровообращения, новообразований и болезней органов дыхания. В России, где не вполне завершена первая эпидемиологическая революция, к этим четырем классам причин смерти примыкают болезни органов пищеварения, они порой даже конкурируют с болезнями органов дыхания. Но зато в России пока нет конкуренции между болезнями органов дыхания и внешними причинами смерти, внешние причины прочно находятся на третьем месте, а иногда и на втором (рисунок 6), внося вклад в общее число смертей, сопоставимый со вкладом новообразований, а то и превосходящий его, что совершенно не характерно для стран с высокой продолжительностью жизни (рисунок 7). 


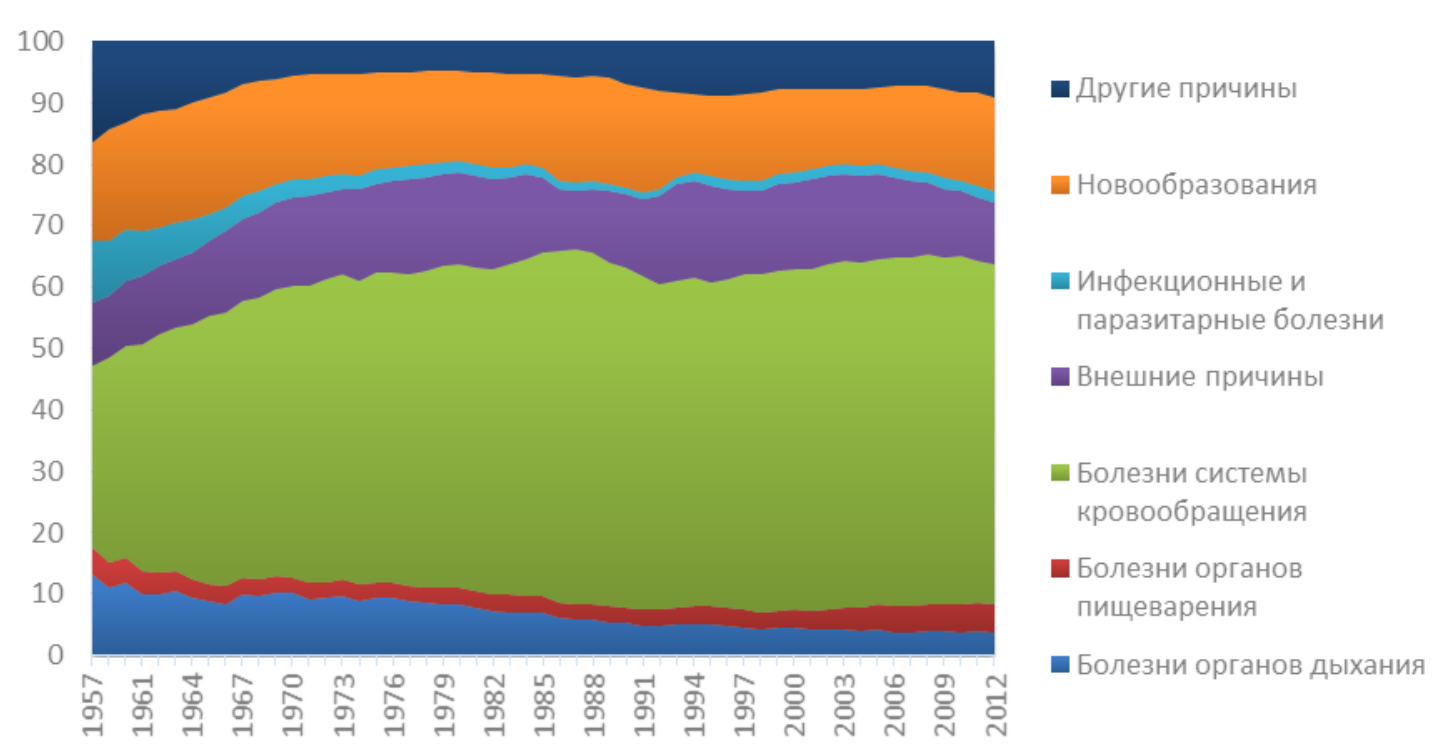

Рисунок 6. Распределение абсолютных чисел умерших по основным классам причин смерти в России, 1956-2012, \%

Источник: Рассчитано по [РосБРиС 2014].
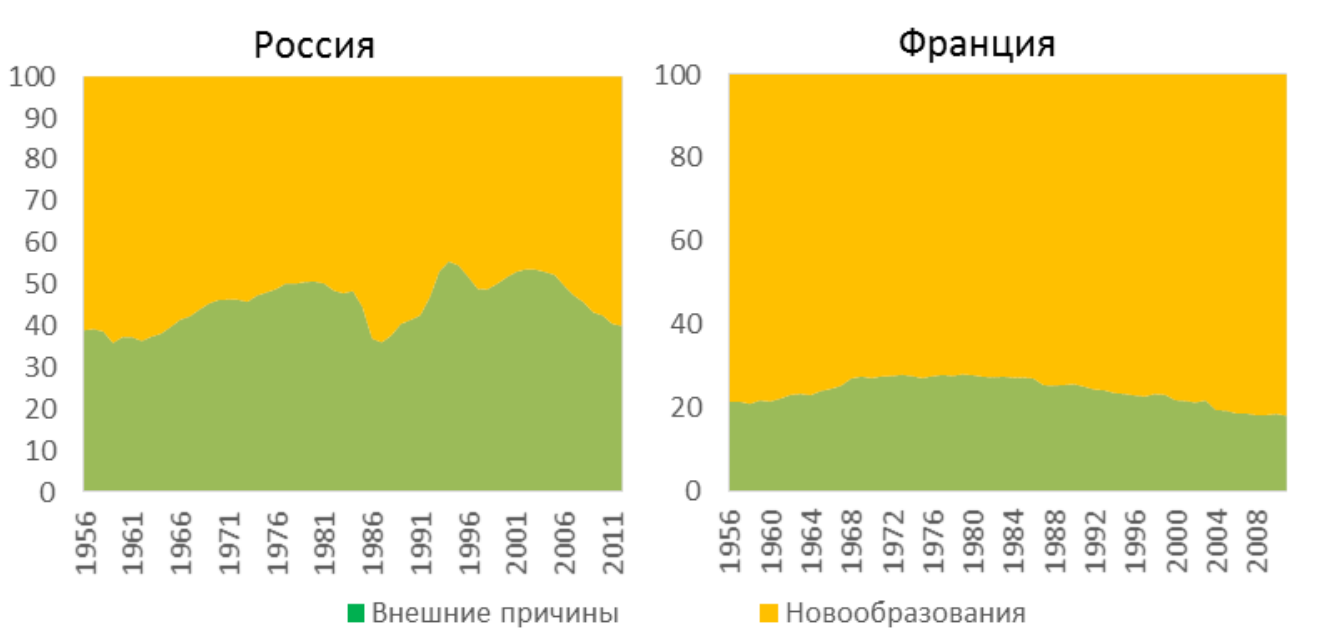

\section{Рисунок 7. Соотношение абсолютных чисел умерших от внешних причин и новообразований в России и во Франции, 1956-2012, \%}

Источник: Рассчитано по [РосБРиС 2014; WНО МDВ 2014].

Вдобавок ко всему необходимо учитывать, что в результате воздействия внешних причин растет число травмированных и потерявших трудоспособность, намного превосходящее число смертей. Об этом свидетельствует и мировой опыт. В докладе ВОЗ за 2006 г. отмечается, что ежедневно в Европейском регионе от внешних причин погибали около 2000 человек, 60 тыс. попадали в больницы, а 600 тыс. вынуждены были обращаться за неотложной амбулаторной помощью [ВОЗ 2006]. 


\section{СМЕРТНОСТЬ ОТ ВНЕШНИХ ПРИЧИН ПО ПОЛУ И ВОЗРАСТУ}

Несмотря на обычное третье-четвертое место по числу вызванных внешними причинами смертей, они везде занимают первое место среди причин преждевременной смертности, потому что «травматической смертности значительно сильнее, чем смертности от болезней, подвержены дети, молодежь и взрослые люди в возрасте до 45 лет» [Демографическая модернизация 2006: 338]. Смертность от внешних причин в России демонстрирует как общие для всех стран различия по полу и возрасту, так и специфические особенности, характерные для нашей страны.

Хотя этот вид смертности у мужчин всегда выше, чем у женщин, в России разрыв особенно велик. Стандартизованный коэффициент смертности женщин от внешних причин в России сопоставим с соответствующим показателем для мужчин в странах Западной Европы, при этом у мужчин в России он выше женского в $4-4,5$ раза, тогда как в 15 взятых для сравнения странах - примерно в 2,5 раза (рисунок 8).

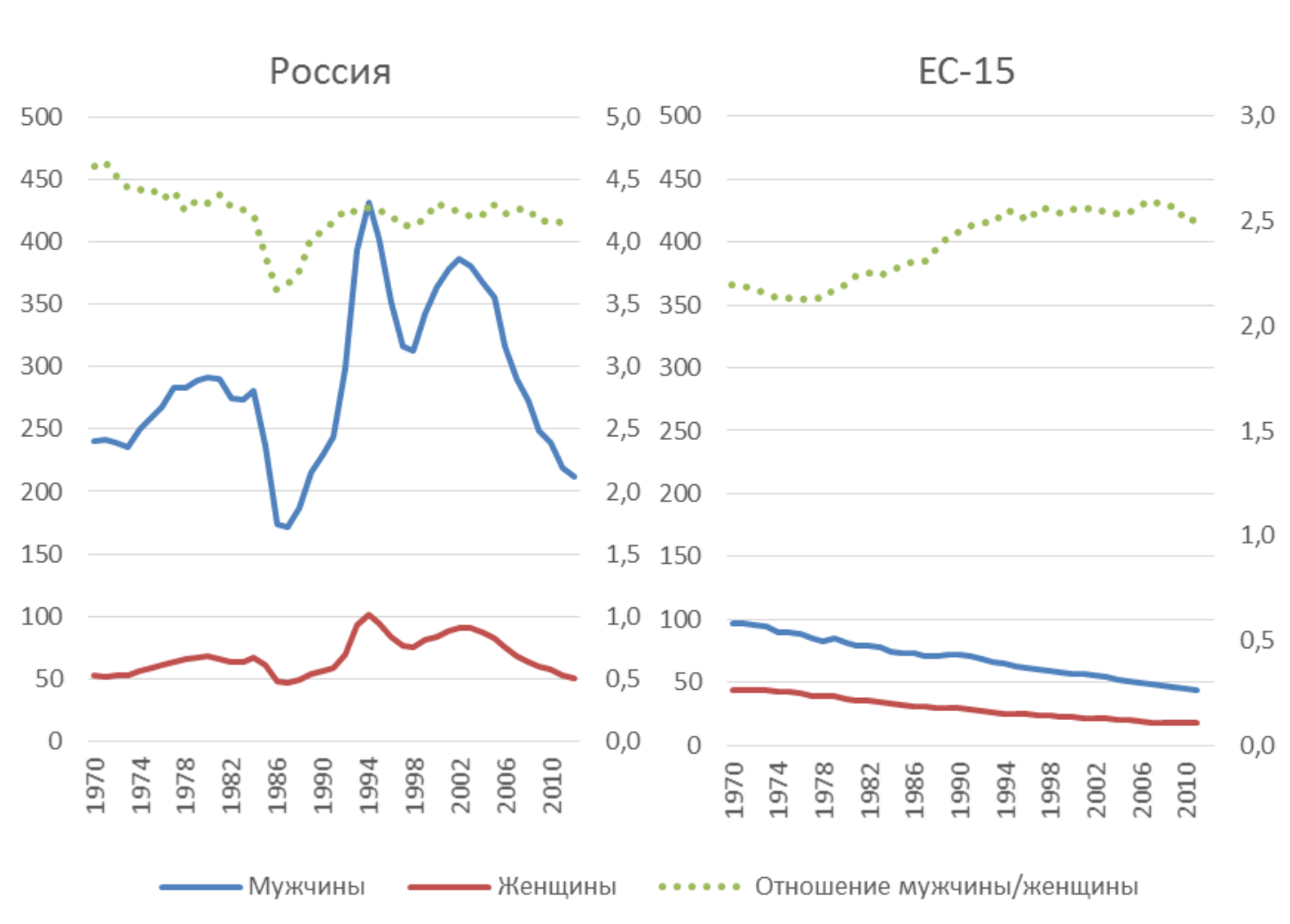

Рисунок 8. Стандартизованный коэффициент смертности от внешних причин на 100 тыс. населения соответствующего пола и отношение мужского показателя к женскому (правая шкала, раз) в России и в ЕС-15, 1970-2012

Источник: Рассчитано по [РосБРиС 2014; WHO HFA 2014].

Смертность от внешних причин особенно заметна в «молодежных» возрастах, когда другие причины смерти еще не набирают силу. В 2012 г. доля обусловленных внешними причинами смертей во всех смертях и у мужчин, и у женщин достигала пика в возрасте 15 19 лет (рисунок 9). 

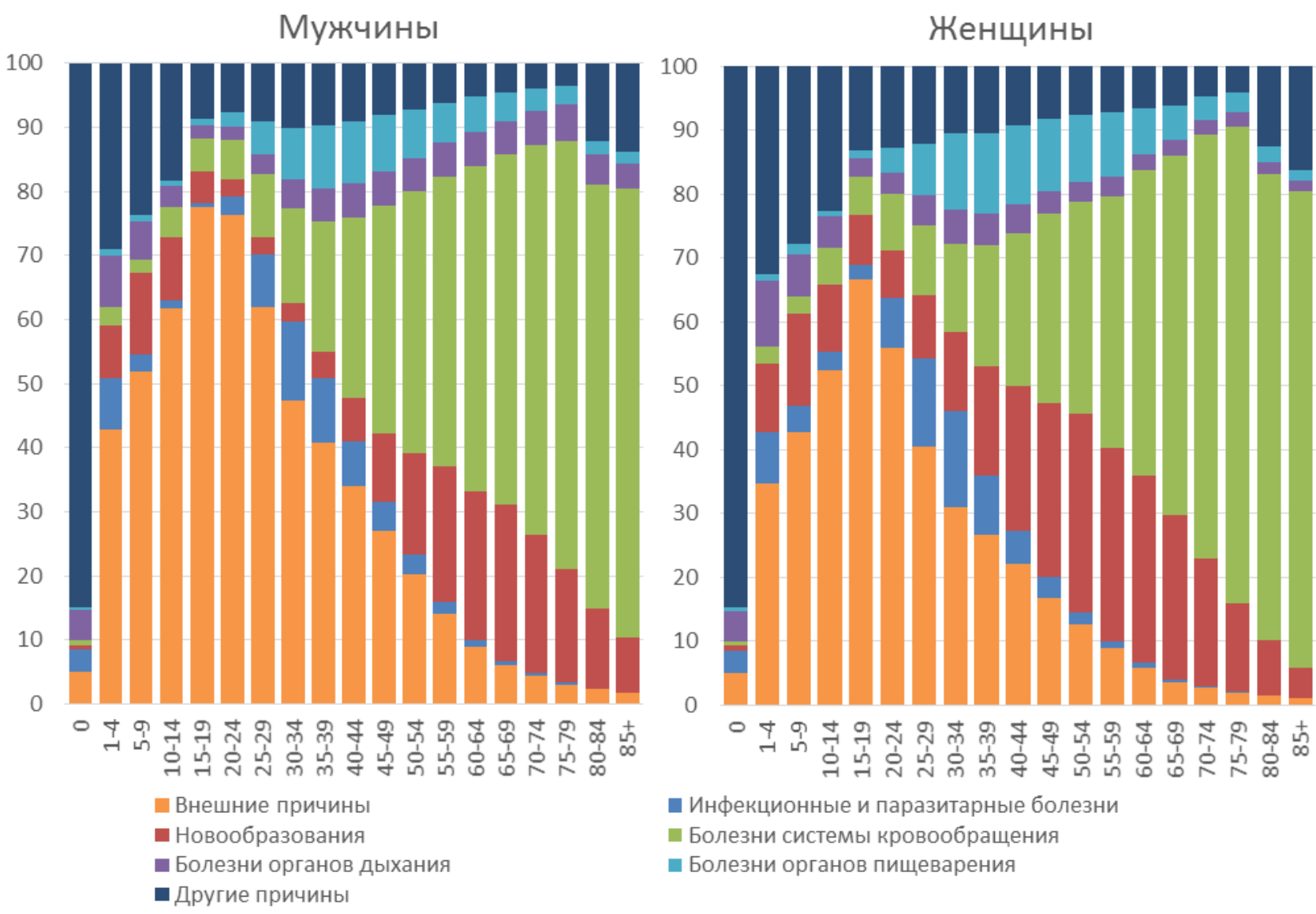

\section{Рисунок 9. Распределение числа смертей по основным классам причин смерти в разных возрастах в России, 2012, \%}

Источник: Рассчитано по [РосБРиС 2014].

Хотя от года к году вклад этого вида смертности в общую смертность в различных возрастах может несколько изменяться, на практике такие изменения не очень значительны. Длительное время максимум такого вклада у мужчин в России приходился на возрастную группу 20-24 года, начиная с 1999 г. он сместился на группу 15-19 лет; у женщин максимум устойчиво приходится на 15-19 лет (рисунок 10).

Снижение доли умерших от внешних причин после достижения максимальных значений в 15-25 лет объясняется не тем, что смертей от внешних причин становится меньше, а тем, что с возрастом нарастает смертность от других причин. Уровень же смертности от внешних причин в расчете на 100 тыс. человек возрастной группы, наоборот, может увеличиваться. Во всяком случае, в России происходит именно так: возрастные коэффициенты смертности от внешних причин достигают наивысших значений в трудоспособных возрастах (от 20 до 60 лет для разных причин этого класса), затем снижаются и вновь растут уже в старости; на графике это выглядит как появление «горба травматической смертности» (рисунок 11). Особенно этот горб был заметен в 1993-1995 гг., когда показатели смертности от внешних причин у мужчин средних возрастов были выше, а у женщин сопоставимы со смертностью в самых старших возрастах. Возрастной «горб травматической смертности» характерен не только для всего класса внешних причин в целом, но и едва ли не для каждого ее вида. По отдельным группам внешних причин, 
прежде всего транспортным несчастным случаям, самоубийствам, убийствам, и особенно повреждениям с неопределенными намерениями, он выражен еще более существенно и всегда заметно выше у мужчин.

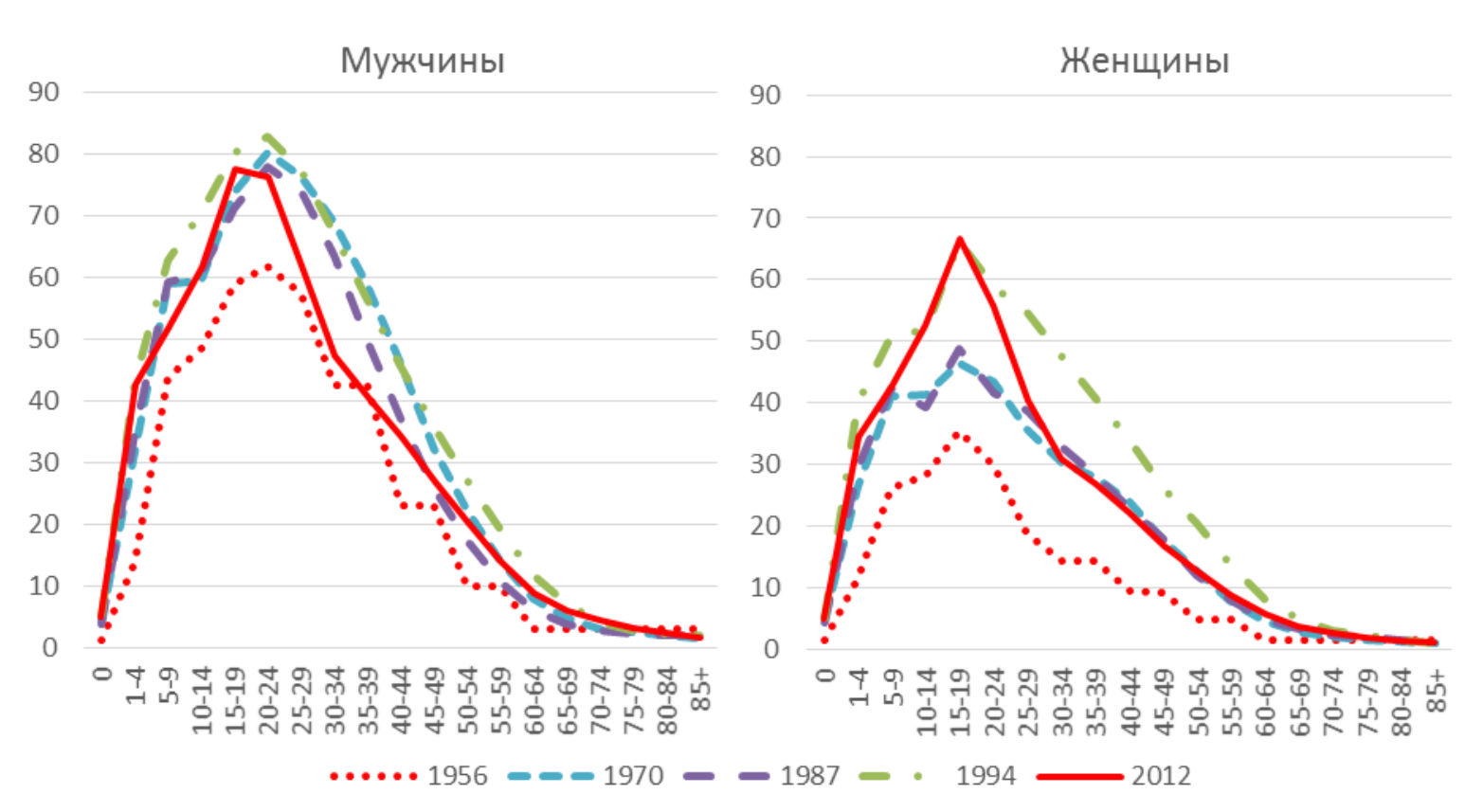

Рисунок 10. Доля смертей от внешних причин во всех смертях по возрасту и полу в России, 1956, 1970, 1987,1994 и 2012, \%

Источник: Рассчитано по [РосБРиС 2014].

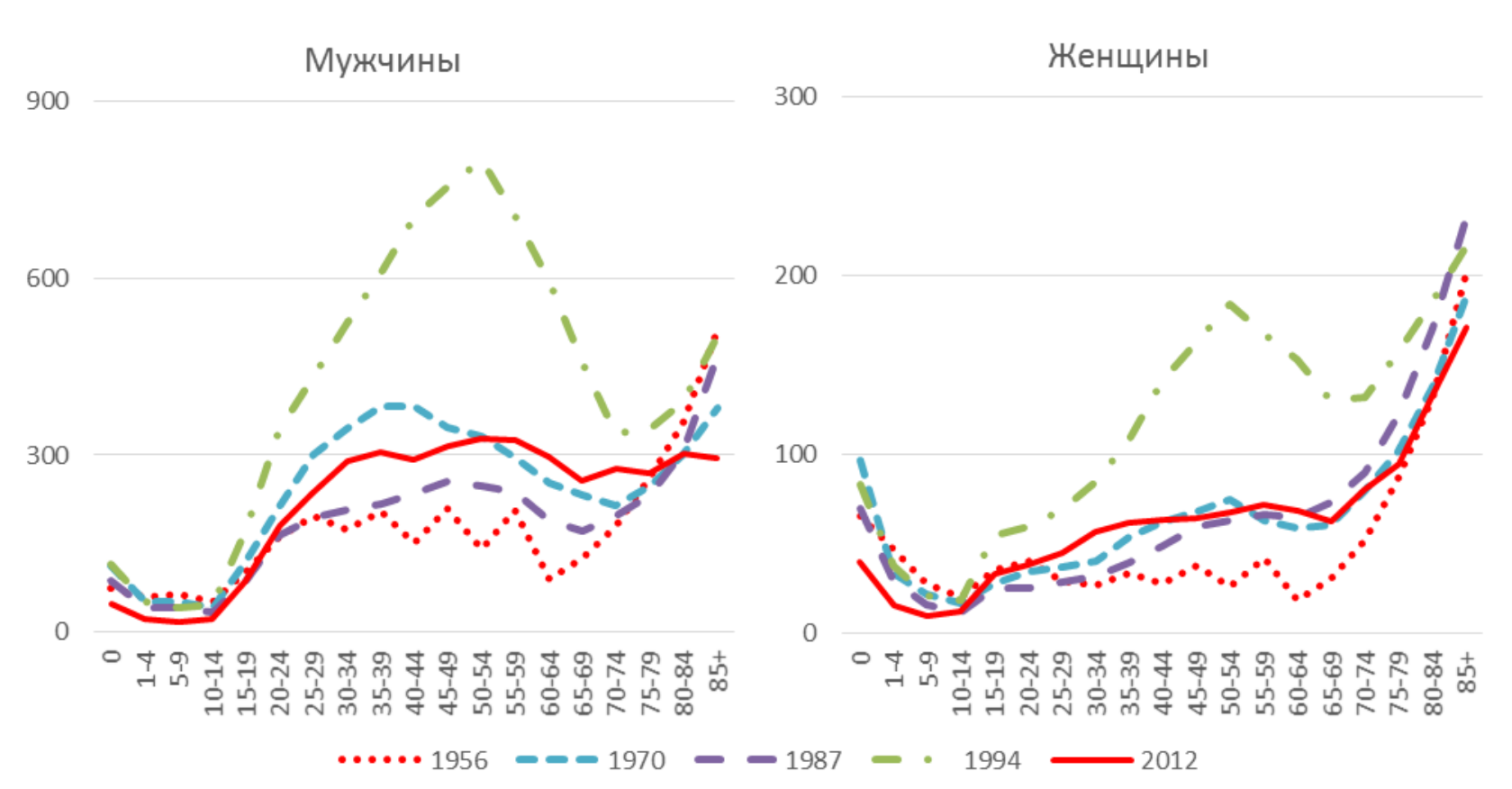

Рисунок 11. Возрастные коэффициенты смертности от внешних причин в России, 1956, 1965, 1970, 1987, 1994 и 2012, на 100 тыс. населения соответствующего пола и возраста

Источник: Рассчитано по [РосБРиС 2014]. 
Возрастной «горб травматической смертности», приходящийся на основные трудоспособные возраста и приводящий к огромным потерям продолжительности жизни, невыгодно отличает Россию от стран с более низкой смертностью, где этот вид смертности плавно (особенно в странах с самой низкой смертностью) нарастает с возрастом, достигая максимума в преклонные годы (рисунок 12).

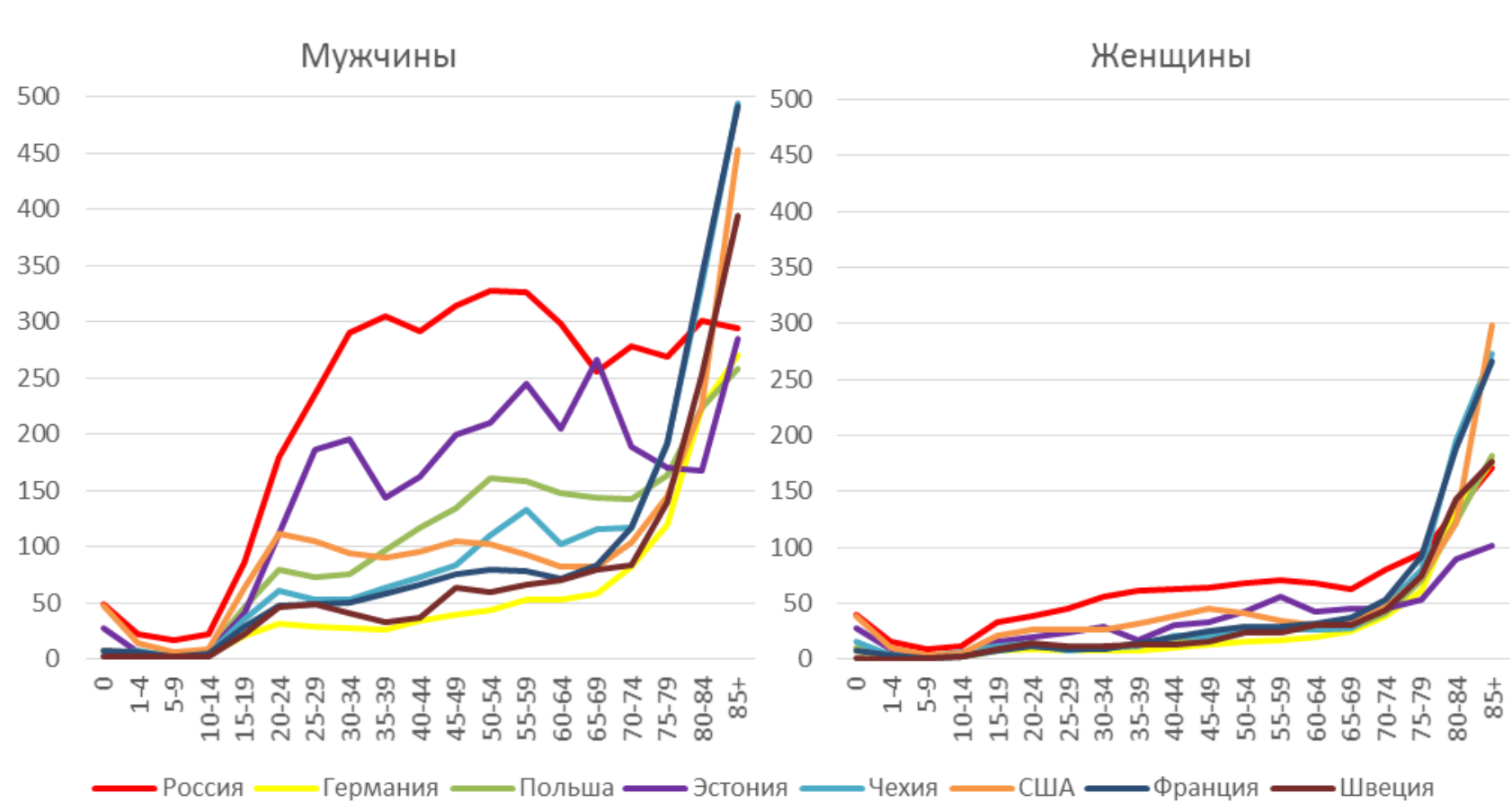

Рисунок 12. Возрастные коэффициенты смертности от внешних причин в России и некоторых западных странах 2010, на 100 тыс. населения соответствующего пола и возраста

Источник: Рассчитано по [РосБРиС 2014; WНО МDВ 2014].

\section{СМЕРТНОСТЬ МУЖЧИН И ЖЕНЩИН ПО ОСНОВНЫМ ВИДАМ ВНЕШНИХ ПРИЧИН СМЕРТИ}

Число возможных внешних причин смерти очень велико, их перечень в международной классификации включает многие относительно редкие причины, вплоть до таких экзотических, как например, залп фейерверка, контакт с ядовитыми змеями и ящерицами или удар молнии. Однако подавляющее большинство смертей обусловлено несколькими группами основных причин, которые в решающей степени определяют общий уровень смертности от внешних причин в целом и поэтому привлекают наибольшее внимание. К ним обычно относят транспортные несчастные случаи (включая ДТП) (коды МКБ 10 V01V99), преднамеренные самоповреждения (самоубийство) (X60-X84), нападения (убийство) (X85-Y09), повреждения с неопределенными намерениями (Y10-Y34), случайные отравления и воздействия ядовитыми веществами (X40-X49) (включая случайные отравления и воздействия алкоголем (X45)), случайные падения (W00-W19), случайные 
утопления (W65-W74) ${ }^{3}$. Список важнейших групп внешних причин смерти, выделяемых при анализе, может несколько изменяться, но в общем он довольно устойчив. Причины смерти, не попавшие в одну из таких выделяемых групп, объединяются в группу «другие несчастные случаи».

В российской структуре внешних причин смерти наибольшая смертность у мужчин связана с такими причинами, как самоповреждения (более 1,8 млн смертей за 1956-2012 гг.), транспортные несчастные случаи, включая ДТП (около 1,4 млн смертей), случайные отравления алкоголем (более 1 млн смертей), повреждения с неопределенными намерениями (около 895 тыс. смертей), замыкают пятерку убийства (около 843 тыс. смертей).

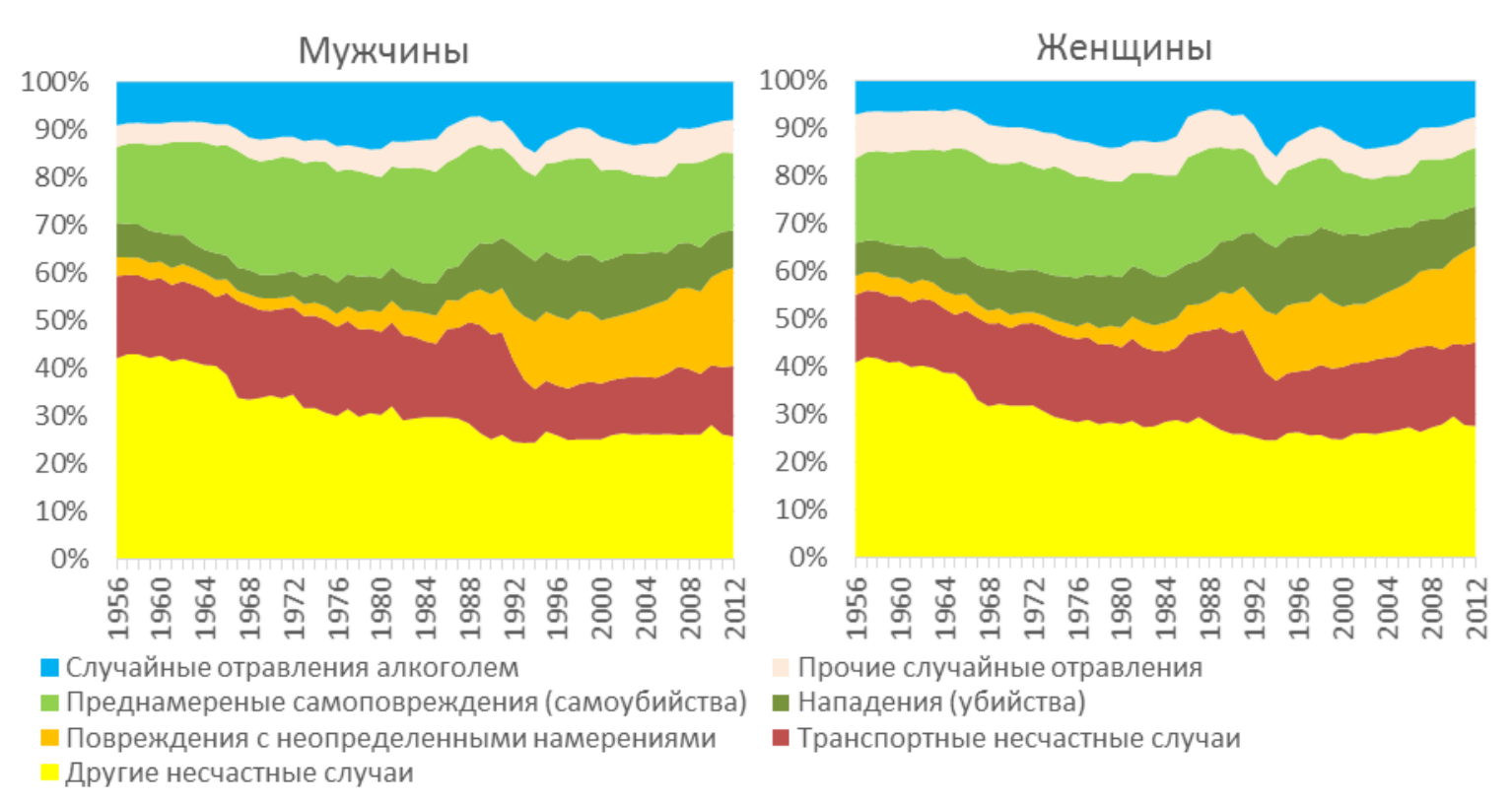

Рисунок 13. Структура внешних причин смерти в России, 1956-2012, \%

Источник: Рассчитано по [РосБРиС 2014].

У женщин наибольшее число смертей в 1956-2012 гг. приходилось на те же причины, что и у мужчин, но с некоторыми отличиями в ранжировании. На первом и втором местах, как и у мужчин, были самоповреждения (около 450 тыс. смертей за весь период) и транспортные несчастные случаи (около 426 тыс. смертей), на третьем месте были нападения (около 299 тыс. смертей), далее следовали случайные отравления алкоголем (около 286 тыс. смертей) и повреждения с неопределенными намерениями (около 252 тыс. смертей). В сумме у обоих полов эти пять причин за 1956-2012 гг. обусловили около 65\% смертей от внешних причин (рисунок 13).

Структура внешних причин смерти не остается неизменной. В ее изменениях в целом за период с 1960 по 2012 г. и у мужчин, и у женщин прежде всего обращает внимание

\footnotetext{
${ }^{3}$ В дальнейшем, для краткости, в рисунках и таблицах используются следующие обозначения основных групп внешних причин: Транспортные несчастные случаи, Преднамеренное самоповреждение (самоубийство), Нападение (убийство), Случайные отравления алкоголем, Прочие случайные отравления, Случайные отравления (включая отравления алкоголем); Повреждения с неопределенными намерениями.
} 
устойчивый рост доли повреждений с неопределенными намерениями при заметном сокращении доли смертей от случайных утоплений и «других несчастных случаев», а у женщин также от самоубийств. Доли всех остальных причин если и менялись, то не особенно существенно, иногда в разных направлениях за периоды 1960-1990 и 1990-2012 гг. Так, доля смертей от нападений, самоповреждений, транспортных несчастных случаев между 1960 и 1990 гг. выросла, однако к 2012 г. сократилась, вследствие чего соотношение долей за последние шесть десятилетий не сильно изменилось. Например, с 1960 до 1990 г. у мужчин доля смертей от транспортных несчастных случаев увеличилась почти на 6 процентных пунктов, после чего к 2012 г. она сократилась более чем на 7 пунктов (с 22 до 15\%), т.е. в итоге с 1960 по 2012 г. доля смертей от этой причины сократилась всего на 1,5 процентного пункта (таблица 1 и рисунок 14).

Таблица 1. Структура умерших от внешних причин смерти мужчин и женщин, 1960, 1990 и 2012

\begin{tabular}{|c|c|c|c|c|c|c|}
\hline \multirow{2}{*}{ Причина смерти } & \multicolumn{3}{|c|}{$\begin{array}{c}\text { Доля во всех смертях от } \\
\text { внешних причин, \% }\end{array}$} & \multicolumn{3}{|c|}{$\begin{array}{c}\text { Прирост (сокращение) доли, } \\
\text { п. п. }\end{array}$} \\
\hline & 1960 & 1990 & 2012 & $\begin{array}{l}1960- \\
1990\end{array}$ & $\begin{array}{l}1990- \\
2012\end{array}$ & $\begin{array}{l}1960- \\
2012\end{array}$ \\
\hline \multicolumn{7}{|c|}{ Мужсчины } \\
\hline $\begin{array}{l}\text { Случайное отравление (воздействие) } \\
\text { алкоголем }\end{array}$ & 8,7 & 8,4 & 8,0 & $-0,4$ & $-0,4$ & $-0,8$ \\
\hline $\begin{array}{l}\text { Прочие случайные отравления } \\
\text { ядовитыми веществами }\end{array}$ & 4,4 & 5,8 & 6,9 & 1,4 & 1,1 & 2,5 \\
\hline Случайное падение & 1,8 & 3,1 & 4,2 & 1,2 & 1,1 & 2,3 \\
\hline Случайное утопление & 14,7 & 6,4 & 4,6 & $-8,3$ & $-1,8$ & $-10,1$ \\
\hline $\begin{array}{l}\text { Повреждения с неопределенными } \\
\text { намерениями }\end{array}$ & 3,5 & 8,4 & 20,6 & 4,9 & 12,2 & 17,1 \\
\hline Нападение (убийство) & 6,1 & 10,5 & 7,8 & 4,5 & $-2,7$ & 1,8 \\
\hline $\begin{array}{l}\text { Преднамеренные самоповреждения } \\
\text { (самоубийство) }\end{array}$ & 18,5 & 19,9 & 16,3 & 1,4 & $-3,6$ & $-2,2$ \\
\hline $\begin{array}{l}\text { Транспортные несчастные случаи } \\
\text { (включая ДТП) }\end{array}$ & 16,3 & 22,0 & 14,8 & 5,7 & $-7,2$ & $-1,5$ \\
\hline Другие несчастные случаи & 26,0 & 15,6 & 16,9 & $-10,4$ & 1,3 & $-9,1$ \\
\hline Всего & 100,0 & 100,0 & 100,0 & & & \\
\hline \multicolumn{7}{|c|}{ Женцины } \\
\hline $\begin{array}{l}\text { Случайное отравление (воздействие) } \\
\text { алкоголем }\end{array}$ & 6,4 & 7,2 & 7,5 & 0,8 & 0,3 & 1,1 \\
\hline $\begin{array}{l}\text { Прочие случайные отравления } \\
\text { ядовитыми веществами }\end{array}$ & 8,4 & 7,0 & 6,4 & $-1,4$ & $-0,6$ & $-2,0$ \\
\hline Случайное падение & 2,2 & 6,1 & 5,6 & 3,9 & $-0,4$ & 3,5 \\
\hline Случайное утопление & 11,9 & 3,8 & 2,8 & $-8,2$ & $-0,9$ & $-9,1$ \\
\hline $\begin{array}{l}\text { Повреждения с неопределенными } \\
\text { намерениями }\end{array}$ & 3,7 & 8,2 & 20,2 & 4,5 & 12,0 & 16,5 \\
\hline Нападение (убийство) & 6,9 & 11,2 & 8,4 & 4,3 & $-2,8$ & 1,5 \\
\hline $\begin{array}{l}\text { Преднамеренные самоповреждения } \\
\text { (самоубийство) }\end{array}$ & 19,6 & 19,2 & 12,2 & $-0,4$ & $-6,9$ & $-7,4$ \\
\hline $\begin{array}{l}\text { Транспортные несчастные случаи } \\
\text { (включая ДТП) }\end{array}$ & 13,8 & 21,1 & 17,5 & 7,3 & $-3,5$ & 3,7 \\
\hline Другие несчастные случаи & 27,2 & 16,3 & 19,3 & $-10,9$ & 3,0 & $-7,9$ \\
\hline Всего & 100,0 & 100,0 & 100,0 & & & \\
\hline
\end{tabular}

Источник: Рассчитано по [РосБРиС 2014].

Примечание: Цветом выделены числа смертей, занимавшие, в порядке убывания, первое (красный), второе (зеленый) и третье (желтый) места. 
Структура внешних причин смерти, сформировавшаяся к 2012 г., представлена на рисунке 14.
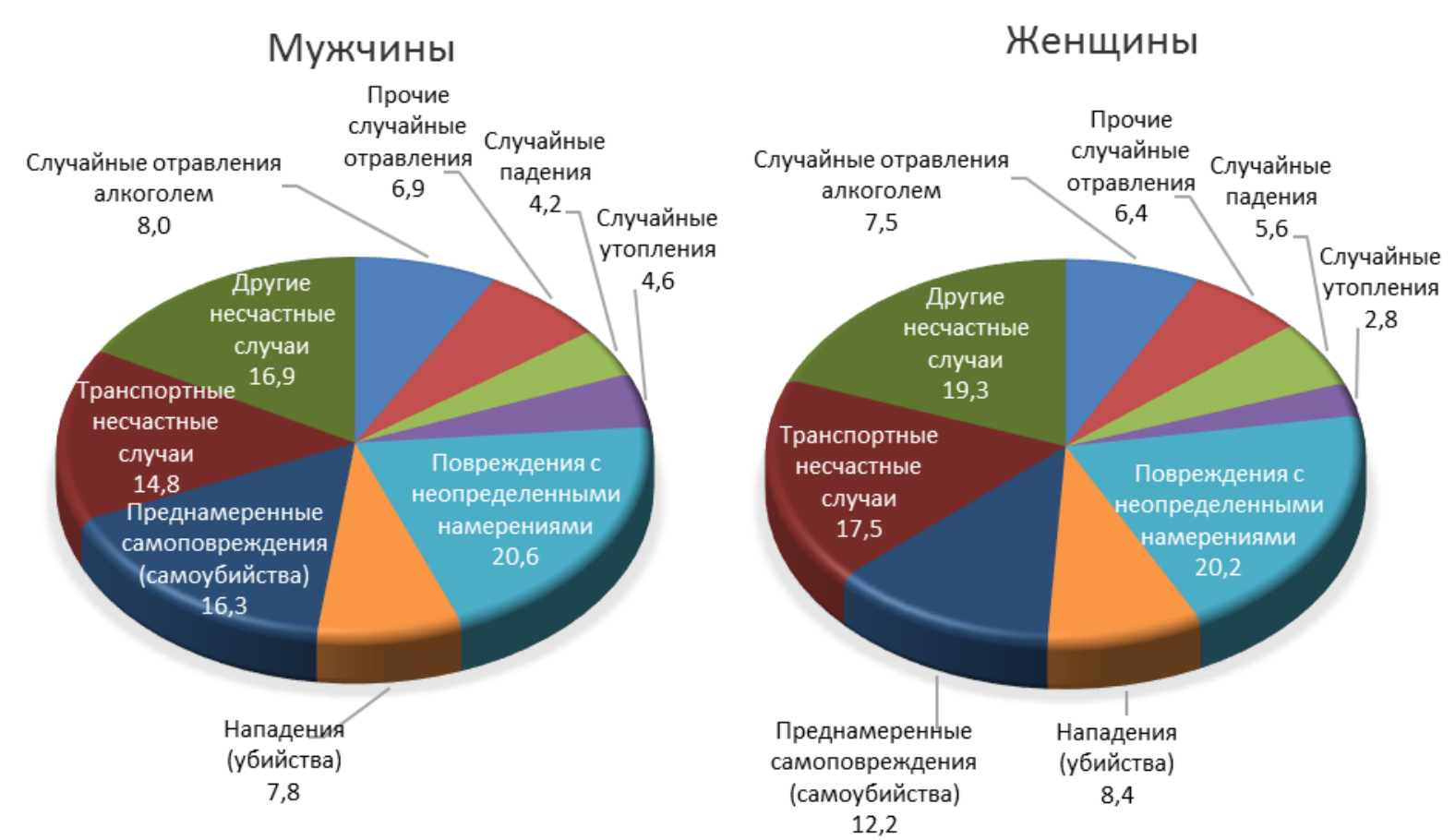

Рисунок 14. Распределение умерших от внешних причин смерти в России по группам причин, 2012, \%

Источник: Рассчитано по [Росстат 2013].

К 2012 г. наблюдается положительная, по сравнению с 1990 г., тенденция снижения доли нападений (у обоих полов с 11 до 8\%) и самоповреждений (у мужчин с 20 до 16\%, у женщин с 19 до 12\%). Однако снижение доли смертей от нападений и самоповреждений сопровождается ростом доли повреждений с неопределенными намерениями, куда с высокой вероятностью попадает значительная часть насильственных смертей, что требует их совместного рассмотрения: общая доля этих трех причин положительной динамики не показывает (с 1960 по 2012 г. она увеличилась с 28 до 45\% у мужчин и с 30 до 41\% у женщин).

При сопоставлении российской структуры стандартизованного коэффициента смертности от внешних причин и у мужчин, и у женщин прежде всего бросается в глаза высокая доля повреждений с неопределенными намерениями, хотя по совокупной доле трех причин (повреждения с неопределенными намерениями, убийства и самоубийства) Россия близка к таким странам, как Германия или Швеция, разумеется, при разных уровнях смертности от этих причин.

Если не учитывать «другие внешние причины», то первое ранговое место в западных странах занимают самоубийства, во всех представленных на рисунке 15 странах их доля и у мужчин, и у женщин выше, чем в России. Напротив, по доле погибших от убийств мужчин среди этих стран Россия уступает только США, а по доле убитых женщин - только Эстонии. 


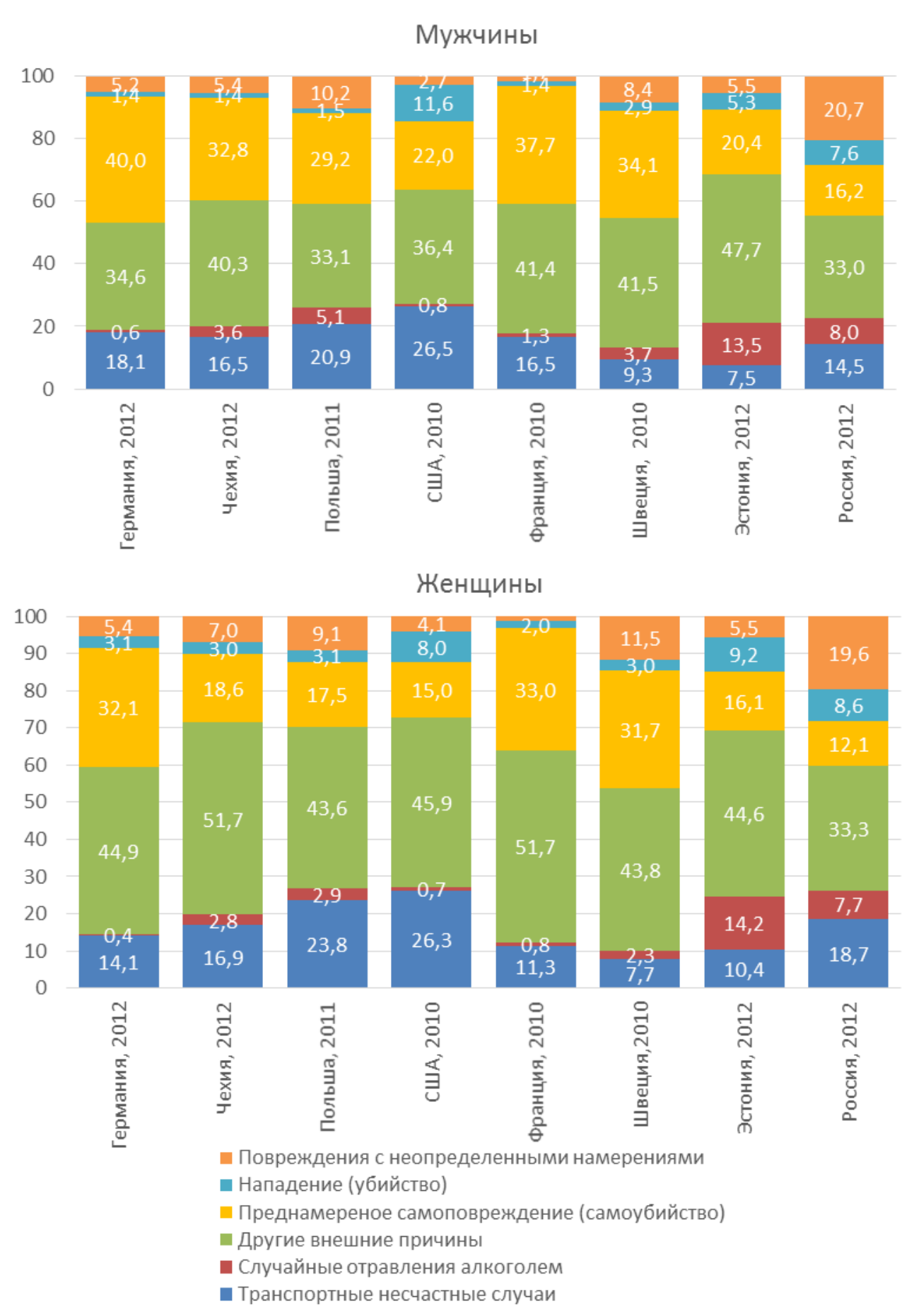

Рисунок 15. Структура стандартизованного коэффициента смертности от внешних причин в России, Германии, Эстонии, Польше, Чехии, Франции, Швеции и США на 100 тыс. населения соответствующего пола

Источник: Рассчитано по [РосБРиС 2014; WНО МDВ 2014].

Во всех странах наибольший вклад в стандартизованный коэффициент смертности от внешних причин вносит группа «другие внешние причины» (все причины, за исключением выделенных на рисунке 15), хотя в России этот вклад, как правило, меньше, чем в других странах. 
Структура «других внешних причин» сильно различается от страны к стране. Например, в США необычно велика доля случайных отравлений, не связанных с алкоголем (вероятно, наркотических); в Германии, Польше и Швеции относительно большую роль играют случайные падения. Россия на общем фоне выделяется высокой долей умирающих от воздействия дыма, огня и пламени, а также от случайных утоплений (рисунок 16).

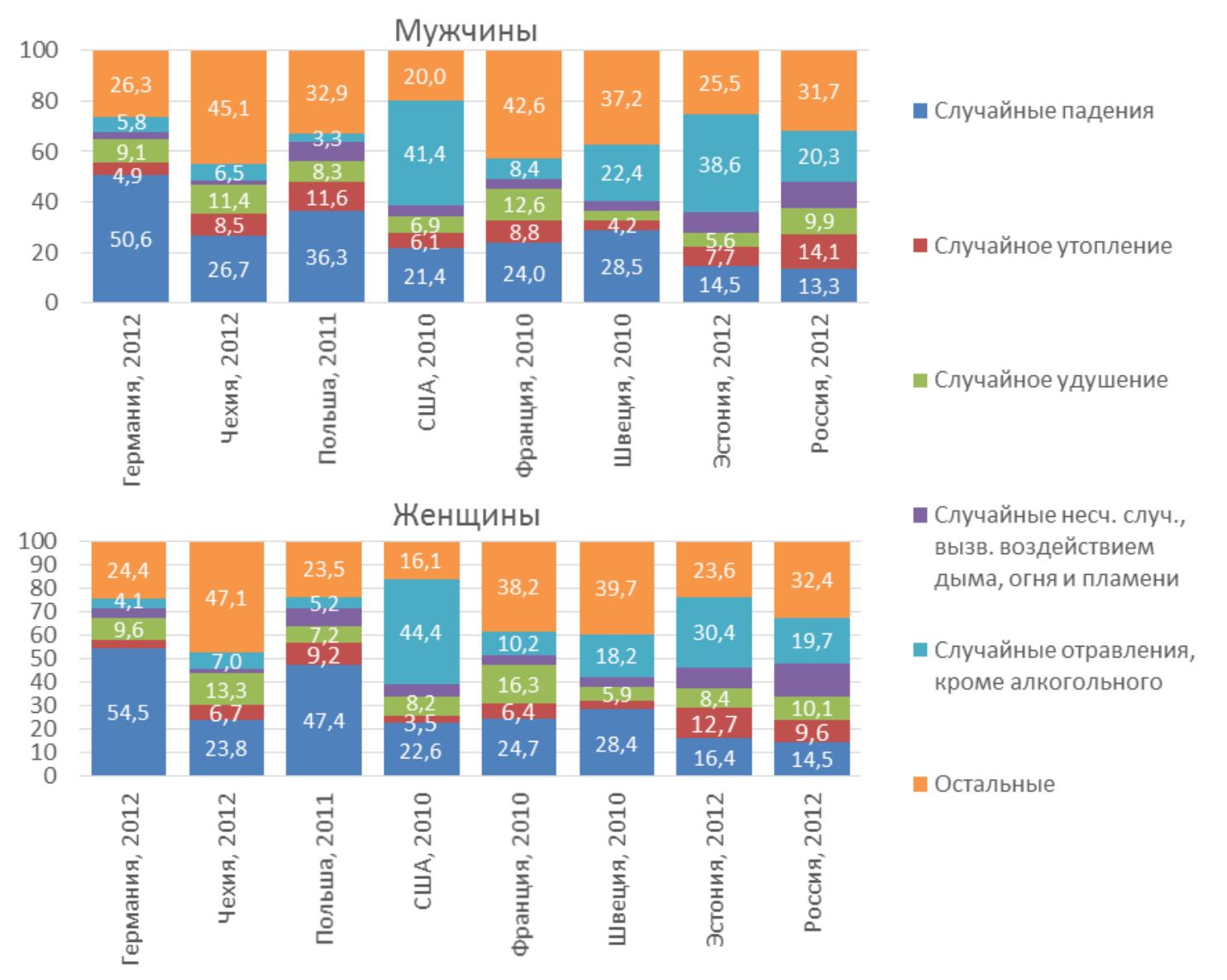

\section{Рисунок 16. Структура стандартизованного коэффициента смертности от «других внешних причин» в России, Германии, Эстонии, Польше, Чехии, Франции, Швеции и США на 100 тыс. населения соответствующего пола}

Источник: Рассчитано по [РосБРиС 2014; WНО МDВ 2014].

В заключение еще раз отметим, что независимо от наблюдающихся сходств или различий в структуре смертности от внешних причин в России и других развитых странах, они имеют лишь ограниченное значение, потому что всегда проявляются на фоне большого отставания России от этих стран по уровню смертности от внешних причин в целом и от большинства входящих в этот класс основных групп причин. Как не раз отмечалось, высокие показатели смертности практически от каждой из внешних причин смерти свидетельство того, что россиянин слабо защищен от неосторожности, халатности или насилия [Вишневский, Школьников 1997]. Тем не менее не следует пренебрегать и структурными различиями, они нередко помогают понять глубинные причины российского отставания. 


\section{ВОЗРАСТНЫЕ ОСОБЕННОСТИ СМЕРТНОСТИ ОТ ОСНОВНЫХ ВИДОВ ВНЕШНИХ ПРИЧИН СМЕРТИ}

Выше мы видели, что смертность от внешних причин в целом обладает определенными возрастными особенностями, отличающими ее от смертности от других причин смерти. Возрастные особенности есть и у смертности от каждой причины или группы внешних причин. Корректное представление об этих особенностях дают так называемые табличные числа смертей $\boldsymbol{d}_{x i}(x$ - возраст, $i$ - причина), соответствующие функции распределения смертей от каждой причины по возрасту из таблиц смертности по причинам смерти.

Использование этих чисел, не зависящих от возрастного состава населения, открывает возможности сравнительного анализа их распределений, характерных для России и других стран. В таблицах 2 и 3 представлены матрицы различий табличных чисел умирающих от различных видов внешних причин по возрастным группам до достижения 70 -летнего возраста в России и, в среднем, в странах EC-15. Разность $\left(d_{x i}^{R}-d_{x i}^{E U-15}\right)$ при ее положительном значении трактуется как избыточное число смертей в данном возрасте от данной причины.

Отличия особенно велики у мужчин: если бы в России, в условном поколении 2010 г., возрастные показатели смертности от соответствующих причин, были такими же, как в целом в странах ЕС-15, то из каждых 100 тыс. фактически зарегистрированных в России мужских смертей более 17 тыс. смертей от внешних причин в возрасте до 70 лет не произошли бы, а были бы оттеснены за этот возрастной предел. Отличия нарастают с возрастом (до наступления 50 лет), наиболее велики они в возрастном интервале от 20 до 50 лет. Наибольший вклад в этот рост вносят самоубийства в возрасте от 20 до 45 лет, убийства - от 30 до 40 лет и особенно отравления и «другие внешние причины» во всех возрастах, начиная с 20 лет.

У женщин отличия также заметны, но они намного меньше: избыточное по сравнению со странами ЕС-15 число смертей от внешних причин в возрасте до 70 лет (около 4400 на 100 тыс. смертей) у них примерено в 4 раза меньше, чем у мужчин. Несколько поиному выглядит и вклад различных возрастов и причин смерти. Отличия нарастают с возрастом до достижения 60 лет, становятся особенно заметными после 40 лет, наибольший вклад вносят отравления после 40 и «другие внешние причины» после 45 лет.

Таблицы, подобные таблицам 2 и 3 , были рассчитаны и за другие годы. Они здесь не приводятся, но график на рисунке 17, построенный на основании последних строк таблиц за 1990, 2000 и 2010 гг., свидетельствует об устойчивости иерархии причин смерти, определяющих различия в смертности от внешних причин между Россией и западноевропейскими странами: на первом месте стоят «другие внешние причины», на втором - отравления (видимо, из-за высокой доли алкогольных отравлений), на третьем у мужчин - самоубийства, у женщин - убийства. Эта иерархия может рассматриваться как один из аргументов при определении приоритетов политики, направленной на снижение смертности от внешних причин. 
Таблица 2. Избыточные табличные числа $\left(d_{x i}^{R}-d_{x i}^{E U-15}\right)$ мужских смертей от внешних причин в возрасте до 70 лет в России по сравнению с ЕС-15, на 100 тыс. мужчин, умирающих во всех возрастах и от всех причин, 2010

\begin{tabular}{|c|c|c|c|c|c|c|c|}
\hline Возраст, лет & 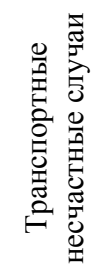 & 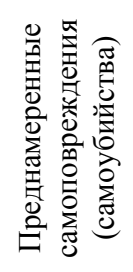 & 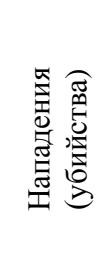 & 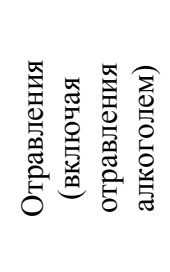 & 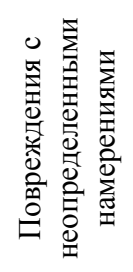 & 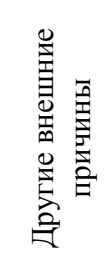 & 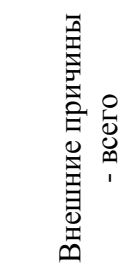 \\
\hline 0 & 3 & 0 & 9 & 2 & 11 & 71 & 97 \\
\hline $1-4$ & 17 & 0 & 6 & 26 & 11 & 95 & 154 \\
\hline $5-9$ & 41 & 2 & 6 & 11 & 7 & 93 & 160 \\
\hline $10-14$ & 35 & 28 & 10 & 7 & 13 & 78 & 171 \\
\hline $15-19$ & 92 & 147 & 85 & 83 & 86 & 192 & 685 \\
\hline $20-24$ & 224 & 321 & 214 & 288 & 219 & 337 & 1603 \\
\hline $25-29$ & 223 & 339 & 281 & 322 & 238 & 340 & 1744 \\
\hline $30-34$ & 210 & 321 & 304 & 299 & 236 & 382 & 1752 \\
\hline $35-39$ & 195 & 301 & 301 & 369 & 248 & 431 & 1845 \\
\hline $40-44$ & 181 & 304 & 290 & 443 & 279 & 493 & 1991 \\
\hline $45-49$ & 160 & 293 & 273 & 478 & 294 & 514 & 2013 \\
\hline $50-54$ & 128 & 255 & 232 & 423 & 288 & 481 & 1806 \\
\hline $55-59$ & 105 & 198 & 176 & 347 & 239 & 409 & 1474 \\
\hline $60-64$ & 80 & 115 & 113 & 247 & 169 & 270 & 994 \\
\hline $65-70$ & 39 & 101 & 61 & 129 & 86 & 118 & 534 \\
\hline Всего & 1734 & 2726 & 2361 & 3476 & 2424 & 4303 & 17023 \\
\hline Число избы & cM & & & & & -100 & Менее 50 \\
\hline
\end{tabular}

Источник: Рассчитано по [РосБРиС 2014; WНО МDВ 2014].

Таблица 3. Избыточные табличные числа $\left(d_{x i}^{R}-d_{x i}^{E U-15}\right)$ женских смертей от внешних причин в возрасте до 70 лет в России по сравнению с ЕС-15, на 100 тыс. женщин, умирающих во всех возрастах и от всех причин, 2010

\begin{tabular}{|c|c|c|c|c|c|c|c|}
\hline Возраст, лет & 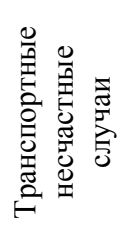 & 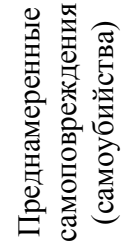 & 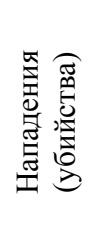 & 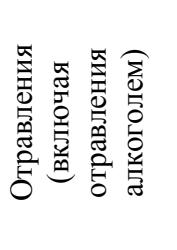 & 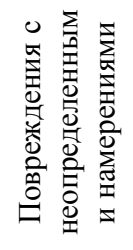 & 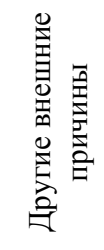 & $\begin{array}{l} \\
\end{array}$ \\
\hline 0 & 2 & 0 & 11 & 3 & 9 & 58 & 83 \\
\hline $1-4$ & 14 & 0 & 6 & 19 & 8 & 62 & 109 \\
\hline $5-9$ & 20 & 0 & 5 & 8 & 5 & 35 & 72 \\
\hline $10-14$ & 19 & 7 & 9 & 3 & 5 & 26 & 70 \\
\hline $15-19$ & 56 & 32 & 38 & 31 & 24 & 35 & 216 \\
\hline $20-24$ & 58 & 30 & 60 & 51 & 39 & 47 & 285 \\
\hline $25-29$ & 57 & 34 & 72 & 45 & 40 & 53 & 300 \\
\hline $30-34$ & 48 & 32 & 78 & 56 & 45 & 61 & 320 \\
\hline $35-39$ & 53 & 28 & 75 & 82 & 51 & 73 & 362 \\
\hline $40-44$ & 49 & 28 & 80 & 106 & 58 & 87 & 408 \\
\hline $45-49$ & 49 & 27 & 82 & 132 & 66 & 109 & 466 \\
\hline $50-54$ & 53 & 27 & 78 & 145 & 75 & 126 & 504 \\
\hline $55-59$ & 51 & 23 & 74 & 157 & 75 & 128 & 506 \\
\hline $60-64$ & 45 & 23 & 56 & 106 & 56 & 94 & 380 \\
\hline $65-70$ & 49 & 31 & 46 & 76 & 40 & 69 & 312 \\
\hline Всего & 622 & 322 & 772 & 1020 & 596 & 1061 & 4393 \\
\hline \multicolumn{4}{|c|}{ Число избыточных смертей: } & $100-300$ & & & ee 50 \\
\hline
\end{tabular}

Источник: Рассчитано по [РосБРиС 2014; WHO МDB 2014]. 

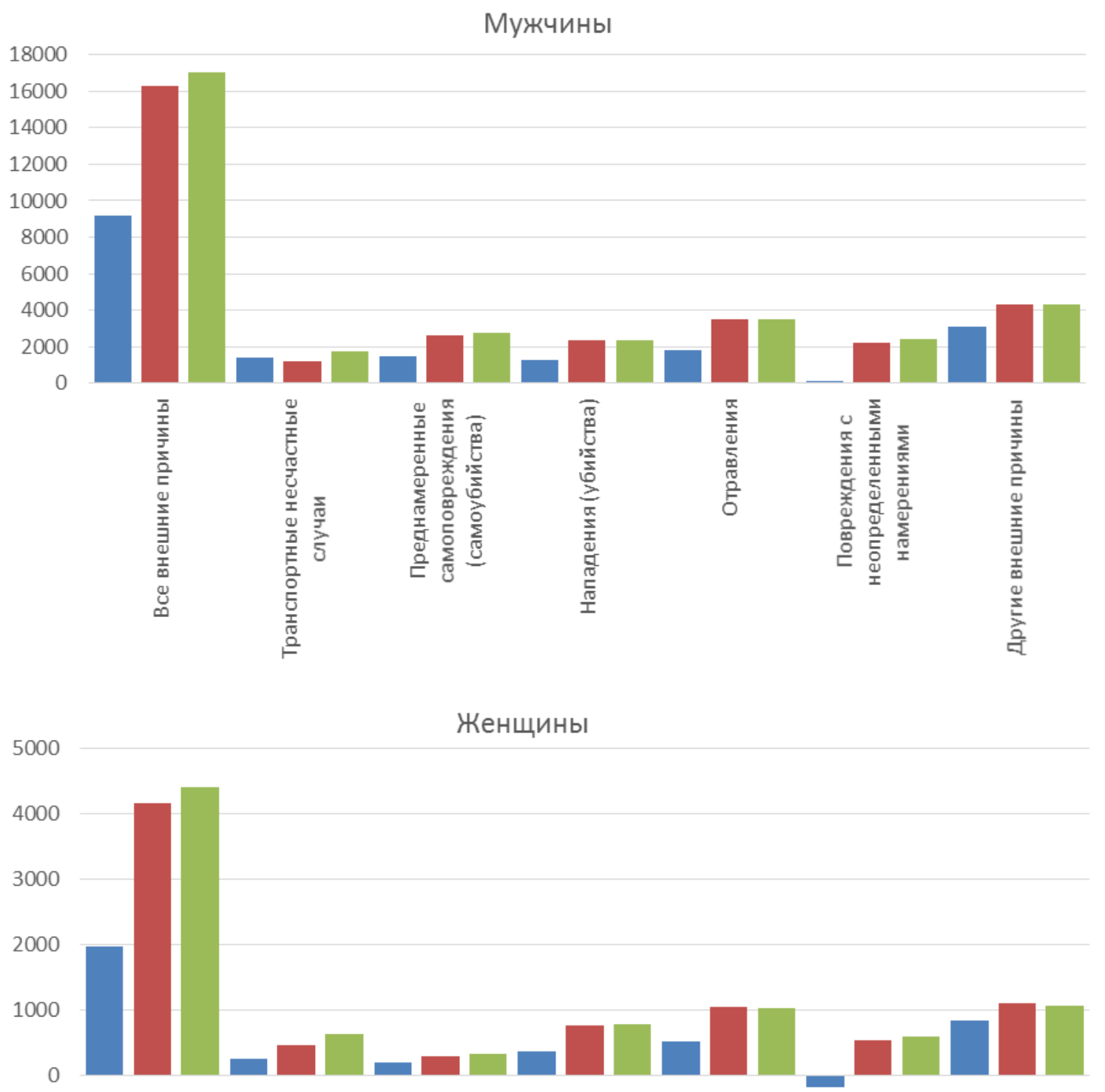

$-1000$

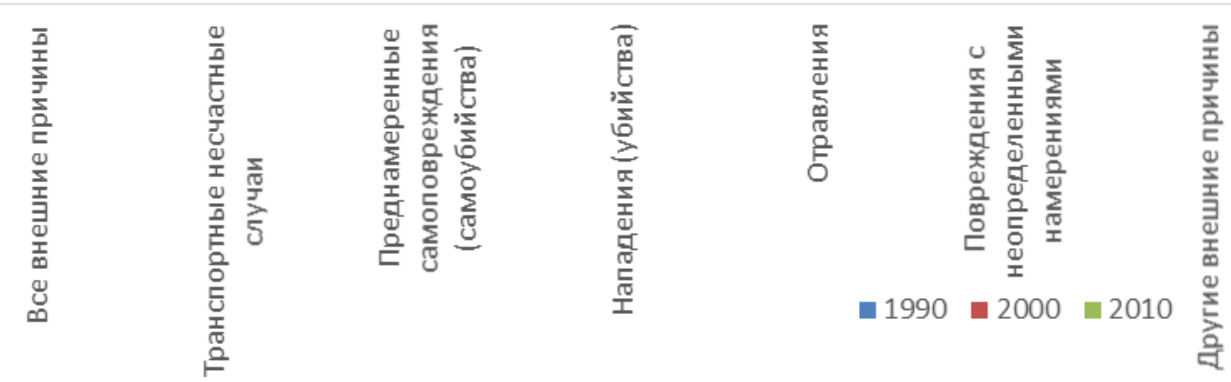

Рисунок 17. Избыточные табличные числа $\left(d_{x i}^{R}-d_{x i}^{E U-15}\right)$ смертей от внешних причин в возрасте до 70 лет в России по сравнению с ЕС-15, 1990, 2000 и 2010

Источник: Рассчитано по [РосБРиС 2014; WHO МDВ 2014]. 


\section{СМЕРТНОСТЬ ОТ ВНЕШНИХ ПРИЧИН И ОЖИДАЕМАЯ ПРОДОЛЖИТЕЛЬНОСТЬ ЖИЗНИ}

Внешние причины - один из двух главных классов причин смерти, определяющих отставание России от большинства развитых стран по ожидаемой продолжительности жизни.

Долговременная динамика этого показателя в России имеет волнообразный характер. Период 1956-1964 гг. характеризовался ростом ожидаемой продолжительности жизни, далее к 1984 г. показатель снизился на 3,6 года у мужчин и на 0,8 года у женщин. С 1985 г., в период проведения антиалкогольной кампании, всего за 3-4 года у мужчин были практически восстановлены все прежние потери ожидаемой продолжительности жизни с 1964 г.: у мужчин ее прирост составил 3,3 года, у женщин - 1,6 года. Демографический успех антиалкогольной кампании оказался недолгим, и уже после ее отмены снижение показателя возобновилось. Всего за 6 лет (к 1994 г.) произошел небывалый обвал показателя: ожидаемая продолжительность жизни «потеряла» более 7,5 года у мужчин и более 3,5 года у женщин. В 1994-1998 гг. показатель снова вырос на 3,8 года у мужчин и на 2,1 года у женщин, что позволило «отыграть» только половину последнего снижения. Кризис 1998 г. привел к новому сокращению показателя за 1999-2003 гг. на 2,7 и 1,3 года у мужчин и женщин соответственно. Наконец, с 2004 по 2012 г. наблюдался рост показателя на 6,1 года у мужчин и 4,2 года у женщин. В 2012 г. ожидаемая продолжительность жизни составила 64,6 года у мужчин и 76 лет у женщин. Эти значения были всего на 2,7 и 5,4 года выше, чем зафиксированные в 1956 г., и примерно соответствовали уровню середины 1960 х годов у мужчин и лишь немного превосходили этот уровень у женщин (рисунок 18).

Мужчины

70

65

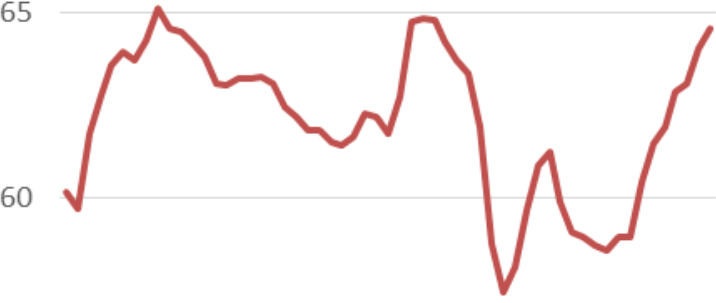

55
80

75

70

Женщины

80

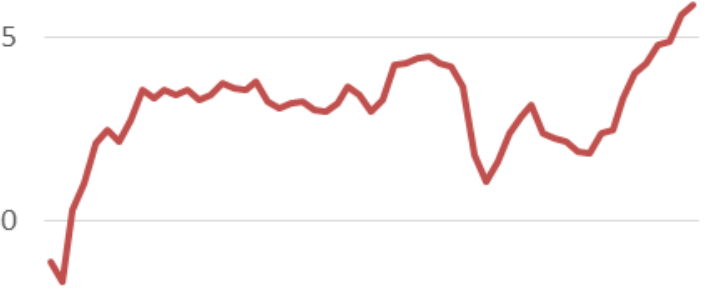

65

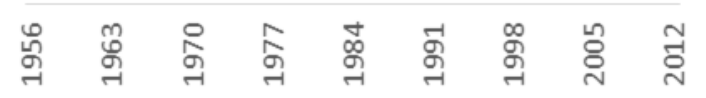

Рисунок 18. Ожидаемая продолжительность жизни мужчин и женщин в России, 1956-2012, лет

Источник: Рассчитано по [Росстат 2013].

Иными словами, если рассматривать длительный период с 1956 по 2012 г., то, несмотря на все колебания, иногда довольно резкие, можно говорить о более чем 
полувековой стагнации ожидаемой продолжительности жизни в России. Как на протяжении всего этого времени влияли на уровень и динамику продолжительности жизни изменения смертности от внешних причин смерти?

Как следует из рисунка 19, и в периоды роста, и в периоды снижения продолжительности жизни в России на протяжении всего временного интервала с 1956 по 2012 г. их вклад в колебания продолжительности был весьма заметным, особенно у мужчин.

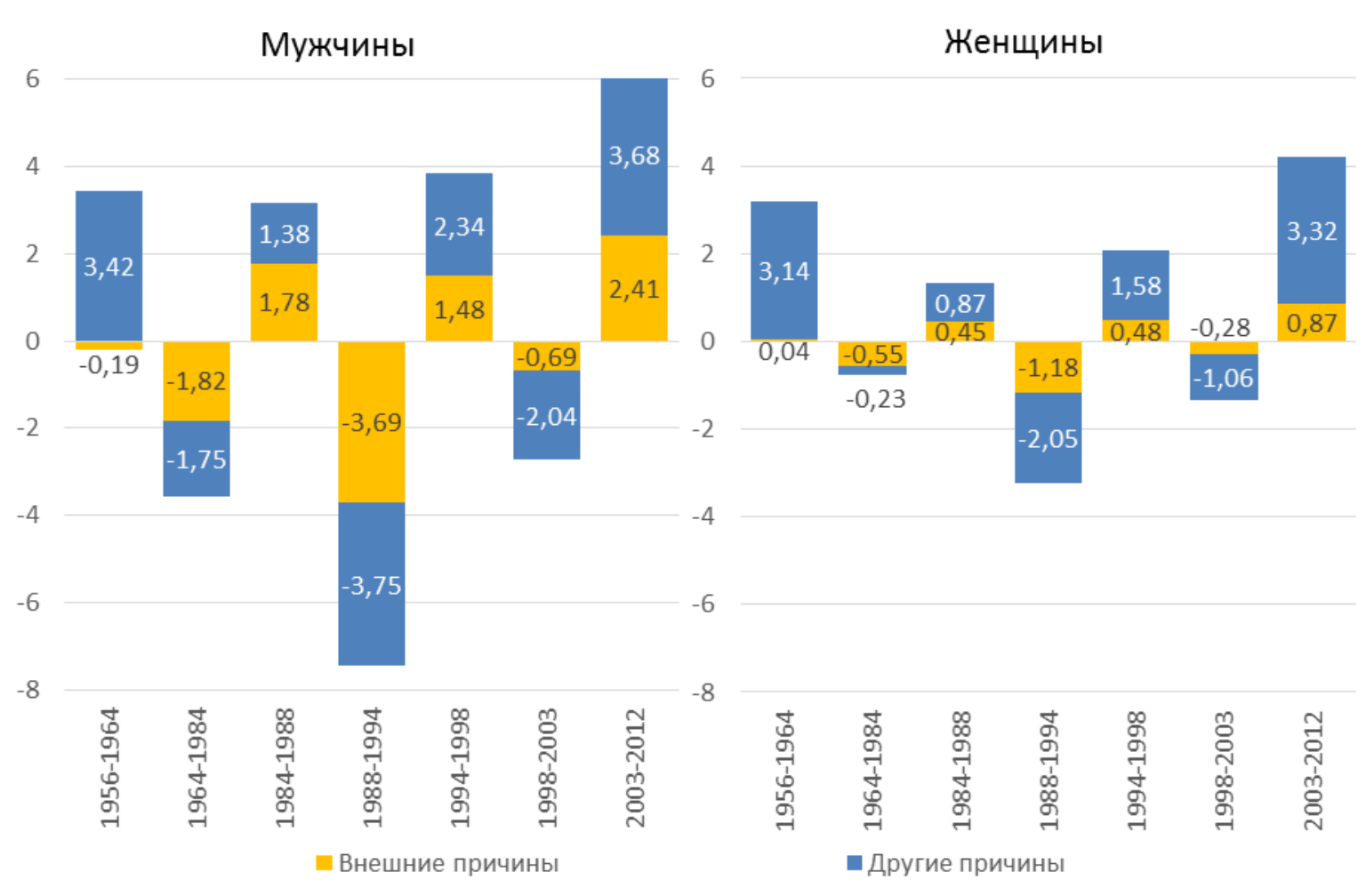

Рисунок 19. Вклад изменений смертности от внешних причин в изменения ожидаемой продолжительности жизни при рождении в периоды ее роста и падения в России с 1956 г. (лет)

Источник: Рассчитано по [РосБРиС 2014].

И на этапах роста, и на этапах снижения ожидаемой продолжительности жизни этот вклад сильно зависел от возраста. В младших и старших возрастных группах он был относительно небольшим, причем в младших возрастах чаще положительным. Решающее же влияние на подъемы и спады продолжительности жизни оказывали изменения смертности от внешних причин в средних возрастах - от 15 до 64 лет (рисунок 20). Благодаря тому, что на участках роста и падения это влияние было почти симметричным, в конечном счете, изменения смертности от внешних причин за 57 лет не слишком повлияли на итоговые изменения ожидаемой продолжительности жизни, хотя все же обусловили ее сокращение почти на 1 год у мужчин. 


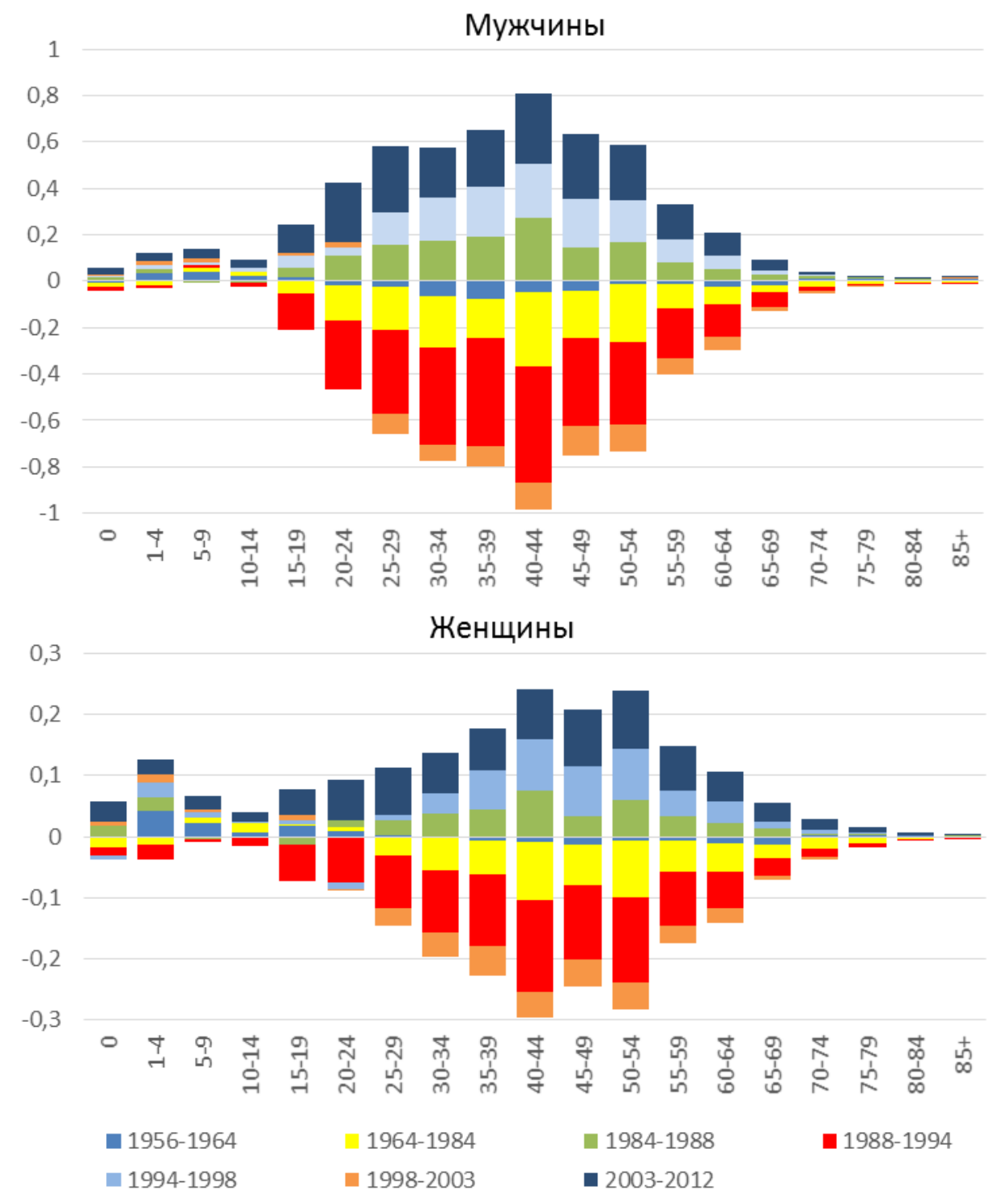

Рисунок 20. Вклад изменений смертности от внешних причин в изменение ожидаемой продолжительности жизни мужчин и женщин по возрастным группам. Россия, 1956-2012, лет

Источник: Рассчитано по [РосБРиС 2014].

Таким образом, наибольший интерес представляет анализ вклада в динамику ожидаемой продолжительности жизни изменений смертности от внешних причин смерти в возрасте 15-64 года. Если принять за точку отсчета ожидаемую продолжительность жизни при рождении в России в 1956 г. (тогда достаточно низкую: 62 года у мужчин и 70 лет у женщин), то прирост или сокращение этого показателя за счет изменений смертности от каждого класса причин в возрастах от 15 до 65 лет позволяет судить, какие классы причин смерти были наиболее важны с точки зрения формирования ожидаемой продолжительности жизни россиян и ее динамики на протяжении всего рассматриваемого периода.

Как следует из рисунка 21, на всем протяжении этого периода положительный вклад в изменение продолжительности жизни и мужчин, и женщин вносило снижение смертности 
от инфекционных заболеваний, хотя величина этого вклада в разные периоды могла быть различной.

У женщин устойчиво позитивный вклад в наращивание отрыва от уровня 1956 г. внесло изменение смертности от других болезней и от новообразований. У мужчин влияние этих двух классов причин было менее выраженным и непоследовательным. Начиная с 1990х годов аномальным представляется негативный вклад в ожидаемую продолжительность жизни роста смертности взрослого населения от болезней органов пищеварения.

Но более всего бросается в глаза неблагоприятное влияние на динамику ожидаемой продолжительности жизни (при наличии резких колебаний) изменений смертности от болезней системы кровообращения и особенно от внешних причин.

Уже к концу 1970-х гг. снижение ожидаемой продолжительности жизни по сравнению с 1956 г. из-за возросшей смертности от внешних причин в возрасте 15-64 года составило 2,3 года у мужчин и 0,5 года у женщин. К 1994 г. это снижение достигло максимальных значений: 4,1 года у мужчин и 1,2 года у женщин. На графике колебания кривых, относящихся к болезням системы кровообращения, во многом повторяют колебания кривых для внешних причин, но все же потери от этих болезней меньше. С середины 1980-х годов обе линии уже в третий раз движутся в направлении положительной полуплоскости, но пока хотя бы ненадолго перейти на нее удавалось только болезням системы кровообращения и только у женщин (в 1986-1991 гг., а также с 2011 г.). Кривая же, соответствующая накопленному вкладу в изменение продолжительности жизни изменений в смертности от внешних причин, остается единственной, никогда не выходившей из отрицательной полуплоскости. К 2012 г. высокая смертность от внешних причин в возрастах 15-64 года, все еще не вернувшаяся к уровню 1956 г., обусловливала потери ожидаемой продолжительности жизни по сравнению с этим исходным годом примерно на 1,2 года у мужчин и на 0,4 года у женщин.

В целом за 1956-2012 гг. существенный отрицательный вклад в изменение ожидаемой продолжительности жизни при рождении у мужчин (-2,6 года) внес рост смертности в возрасте 15-64 года от болезней системы кровообращения (48\% этого вклада или $-1,2$ года), внешних причин (38\% или -1 год) и болезней системы пищеварения (15\% или $-0,4$ года). Вклад изменений смертности от других классов причин в этой возрастной группе был положительным, но меньшим по величине (1,1 года), поэтому в сумме вклад всех изменений оказался отрицательным (-1,5 года; рисунок 22). У женщин в возрасте 1564 года отрицательный вклад (-0,7 года) также внесли внешние причины (54\% или -0,4 года) и болезни органов пищеварения (46\% или -0,3 года), однако положительный вклад других причин оказался вдвое большим, отчего в данной возрастной группе наблюдается прирост ожидаемой продолжительности жизни к 2012 г. на 0,7 года по сравнению с уровнем 1956 г. 


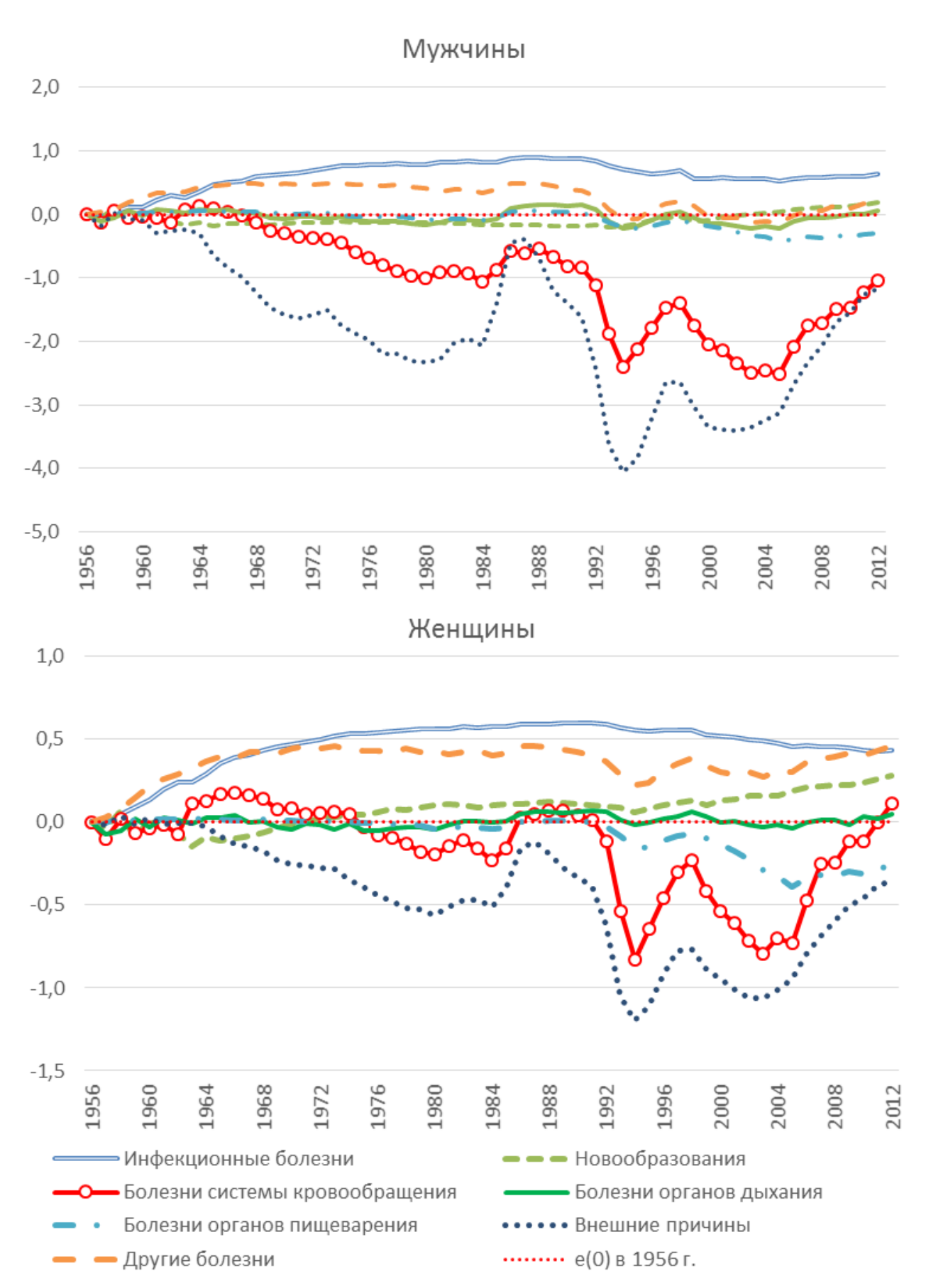

Рисунок 21. Прирост или убыль ожидаемой продолжительности жизни в России после 1956 г. за счет изменений смертности от основных классов причин в возрастах 15-64 года, лет

Источник: Рассчитано по [РосБРиС 2014].

Конечно, ожидаемая продолжительность жизни и мужчин, и женщин сейчас выше, чем была в 1956 г., но в решающей степени, особенно у мужчин, - лишь благодаря компенсирующей роли снижения смертности в детских возрастах. В возрастах до 15 лет у обоих полов в 1956-2012 гг. смертность снижалась от всех крупных классов причин смерти, в том числе и от внешних (у мужчин вклад снижения смертности от внешних причин 
составил 0,3 года от общего прироста в 4,2 года или $8 \%$, у женщин - 0,2 года от прироста в 4,1 года или 5\%).

Рост продолжительности жизни пожилых людей - 65 лет и старше - отмечается только у женщин, и он невелик. Снижения смертности от внешних причин все еще недостаточно, чтобы внести в этот рост хоть какой-то позитивный вклад.

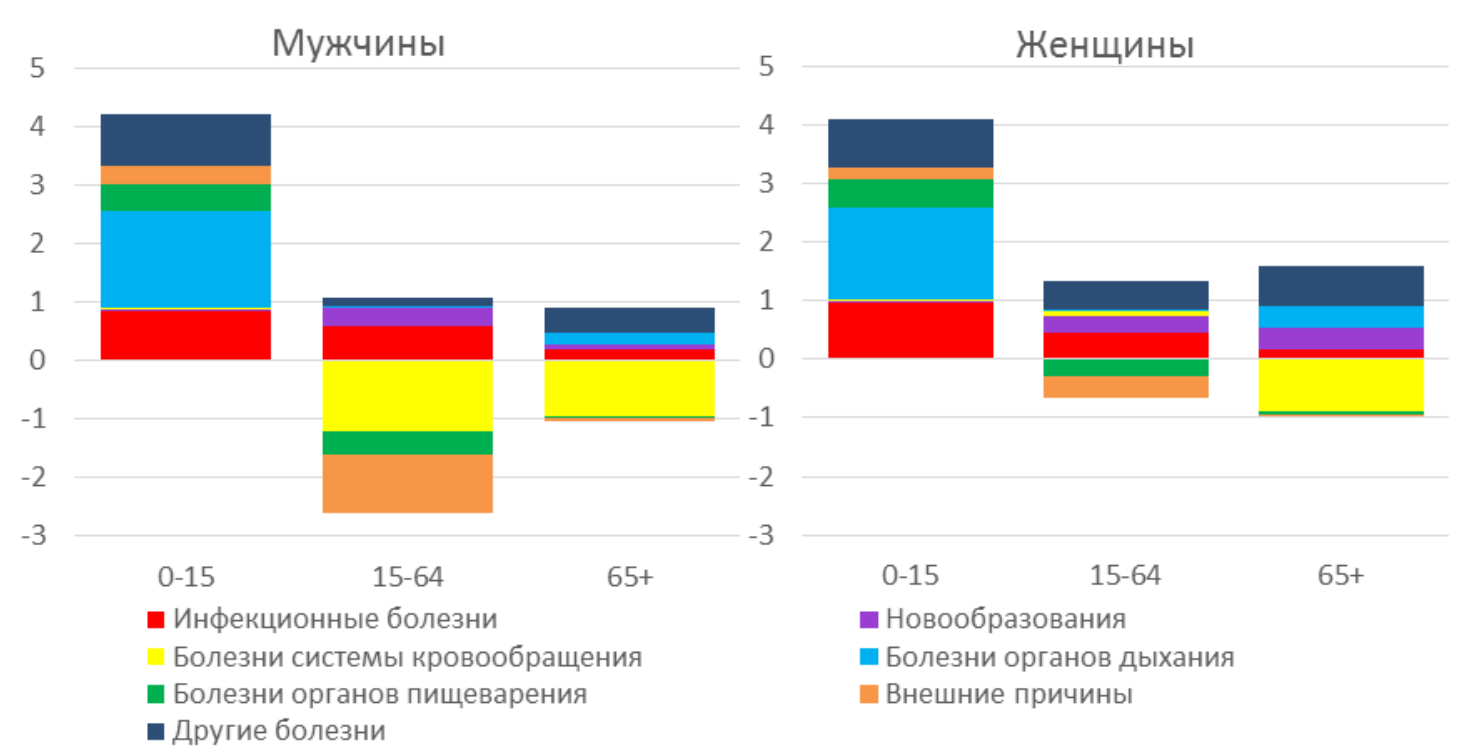

\section{Рисунок 22. Декомпозиция изменений ожидаемой продолжительности жизни в России вследствие изменений смертности по крупным возрастным группам и причинам смерти, 1956-2012, лет}

Источник: Рассчитано по [РосБРиС 2014].

Таким образом, повышение смертности от внешних причин смерти в возрасте 15-64 года и у мужчин, и у женщин оказало весьма значительное негативное влияние на изменения ожидаемой продолжительности жизни за длительный период, причем у мужчин этой возрастной группы оно было почти сопоставимо с негативным влиянием подъемов смертности от болезней системы кровообращения, а у женщин конкурировало с влиянием роста смертности от болезней органов пищеварения, в то время как изменения смертности от болезней системы кровообращения в целом за весь период внесли некоторый позитивный вклад в изменения продолжительности жизни женщин.

В 2012 г. в России продолжительность жизни для обоих полов вместе наконец превысила 70 лет, однако продолжительность жизни мужчин при рождении и, особенно, в возрасте 15 лет все еще была ниже, чем в середине 1960-х годов или в годы антиалкогольной кампании. Продолжительность предстоящей жизни пятнадцатилетних женщин превысила максимум 1960-1988 гг. только на 0,5 года. Таким образом, в последнее десятилетие происходит не столько рост ожидаемой продолжительности жизни, сколько возврат к ранее достигнутым уровням. Отставание от развитых стран сохраняется, а учитывая долговременный колебательный характер изменений смертности от внешних причин и ожидаемой продолжительности жизни, пока трудно сказать, насколько устойчивой окажется положительная динамика показателей, которую мы наблюдаем. 


\section{ЛИТЕРАТУРА}

Богоявленский Д.Д. (2001) Смертность от внешних причин в России // Демоскоп Weekly. № 29-30. URL: http://www.demoscope.ru/weekly/029/tema01.php (дата обращения: 28.10.2014).

Вишневский А., В. Школьников (1997). Смертность в России: главные группы риска и приоритеты действия. Научные доклады Московского Центра Карнеги. Вып.19: 83.

ВО3 (2006). Травматизм и насилие в Европе. В чем важность этой проблемы и что можно сделать. Резюме. ВO3: 26. URL:

http://www.euro.who.int/_data/assets/pdf_file/0008/98405/E87321R.pdf (дата обращения 09.10.2014).

Демографическая модернизация России, 1900-2000 (2006) / Под ред. Вишневского А.Г. М.: Новое издательство.

Милле Ф., В.М. Школьников, В. Эртриш, Ж.Валлен (1996). Современные тенденции смертности по причинам смерти в России, 1965-1994. INED, Paris. URL:

http://demoscope.ru/weekly/knigi/shkol/shkol.html (дата обращения: 28.10.2014).

Российская база данных по рождаемости и смертности (РосБРиС). Центр демографических исследований Российской экономической школы (2014). URL: http://www.demogr.nes.ru/index.php/ru/demogr_indicat/data_description (дата обращения 09.10.2014).

Росстат (2013). Демографический ежегодник России, 2013. Стат. сб. М.: Росстат. URL: http://www.gks.ru/bgd/regl/B13_16/Main.htm (дата обращения: 15.10.2014).

Eurostat Database (Eurostat) (2014) URL:

http://appsso.eurostat.ec.europa.eu/nui/show.do?dataset=demo_mlifetable\&lang=en (дата обращения: 09.10.2014).

Meslé F., J. Vallin, V. Hertrich, E. Andreev, V. Shkolnikov (2003). Causes of death in Russia: assessing trends since the 1950s // European Population Conference «Population of Central and Eastern Europe. Challenges and Opportunities» / Irena E. Kotowska and Janina Józwiak, eds. Statistical Publishing Establishment. Warsaw: 389-414. URL:

http://demoscope.ru/weekly/knigi/epc.php (дата обращения 09.10.2014).

National Center for Health Statistics of USA (NCHS) (2014). Injury and Violence Prevention and Control. URL: www.cdc.gov/injury (дата обращения: 09.10.2014).

World Health Organization European Detailed Mortality Database (WHO DMDB) (2014). URL: http://www.euro.who.int/en/data-and-evidence/databases/european-detailed-mortalitydatabase-dmdb2 (дата обращения: 09.10.2014) .

World Health Organization European Health for all database (WHO HFA-DB) (2014). URL:http://data.euro.who.int/hfadb/ (дата обращения: 09.10.2014).

World Health Organization Mortality DataBase (WHO MDB) (2014). URL:

http://www.who.int/healthinfo/statistics/mortality_rawdata/en/index.html (дата обращения: 09.10.2014). 


\title{
MORTALITY FROM EXTERNAL CAUSES OF DEATH IN RUSSIA OVER THE PAST HALF-CENTURY *
}

\section{EKATERINA KVASHA, TATIANA KHARKOVA, VALERY YUMAGUZIN}

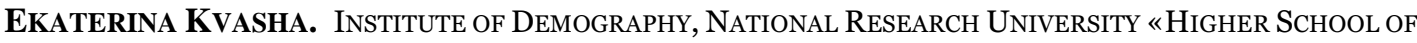
ECONOMICS».E-MAIL: ekvasha@hse.ru.

TATIANA KHARKOVA. Institute OF Demography, National RESEARCh University «Higher SchoOl OF ECONOMICS».E-MAIL: tkharkova@hse.ru.

VALERY YUMAGUZIN. InSTITUTE OF DEMOgRAPHy, NATIONAL RESEARCH UNIVERSITY «Higher SCHOOL OF ECONOMICS». E-MAIL: vyumaguzin@hse.ru.

DATE RECEIVED : OCTOBER 2014.

\begin{abstract}
The article discusses the long-term dynamics (since 1956) of mortality from external causes of death in Russia. Russia has long lagged behind developed countries in terms of the level of mortality from external causes of death, which continues to remain high, as does the structure of such mortality, whose archaism is reflected in the large contribution of homicides, alcohol poisoning and injuries of undetermined intent.

On the basis of life tables, a calculation is made of excess deaths $\left(d_{x}\right)$ in Russia compared with Western European countries. It is shown that in Russia the greatest excess losses are associated with mortality from poisonings among both sexes, suicide among men and murder among women.
\end{abstract}

Mortality from external causes, along with mortality from diseases of the circulatory system, has had a significant impact on life expectancy. In general, in the period 1956-2012, the increase in mortality from external causes in the 15-64 age group reduced life expectancy for males by 2.6 years and women by 0.7 years.

The decline, starting in 2003, of mortality from external causes of death has slightly reduced the gap between Russia and developed countries, bringing Russia closer to the levels of mortality reached in the mid-1960s and 1980s. However, given the fluctuations of mortality from external causes, it is premature to say whether the current decline in mortality is a stable trend.

Key words: mortality in Russia, external causes of death, excess mortality, life expectancy.

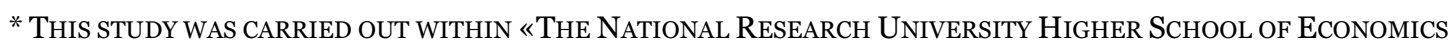
ACADEMIC FUND» PROGRAM, RESEARCH GRANT № 05-0029 «EXTERNAL CAUSES OF DEATH IN THE SYSTEM OF PRIORITIES IN THE FIGHT FOR THE LIFE EXPECTANCY INCREASE IN RUSSIA».
}

\section{REFERENCES}

Bogoyavlensky D. (2001). Smertnost' ot vneshnih prichin v Rossii [Mortality from external causes in Russia] // Demoskope Weekly. № 29-30. URL: http://www.demoscope.ru/weekly/029/tema01.php (data accessed: 28.10.14).

Demograficheskaja modernizacija Rossii [Demographic modernization of Russia], 1900-2000 (2006) / A.G. Vishnevskiy, ed. Moskva.: Novoe izdatel'stvo.

Eurostat Database (Eurostat) (2014) URL:

http://appsso.eurostat.ec.europa.eu/nui/show.do?dataset=demo_mlifetable\&lang=en (data accessed: 09.10.2014). 
Meslé F., J. Vallin, V. Hertrich, E. Andreev, V. Shkolnikov (2003). Causes of death in Russia: assessing trends since the 1950s // European Population Conference «Population of Central and Eastern Europe. Challenges and Opportunities» / Irena E. Kotowska and Janina Józwiak, eds. Statistical Publishing Establishment. Warsaw: 389-414. URL:

http://demoscope.ru/weekly/knigi/epc.php (data accessed: 09.10.2014).

National Center for Health Statistics of USA (NCHS) (2015). Injury and Violence Prevention and Control. URL: http://www.cdc.gov/injury (data accessed: 09.10.2014).

Rossijskaja baza dannyh po rozhdaemosti i smertnosti (RosBRiS). Centr demograficheskih issledovanij Rossijskoj ekonomicheskoj shkoly [Russian database on fertility and mortality. Center for demographic research of the New Economic School] (2014) URL:

http://www.demogr.nes.ru/index.php/ru/demogr_indicat/data_description (data accessed: 09.10.2014).

Rosstat (2013). Demograficheskij ezhegodnik Rossii, 2013 [Demographic Yearbook of Russia, 2013]. Statisticheskij sbornik [Statistical issue]. Moskva: Rosstat. URL: http://www.gks.ru/bgd/regl/B13_16/Main.htm (data accessed: 15.10.2014).

Vishnevsky A., V. Shkolnikov (1997). Smertnost' v Rossii: glavnyye gruppy riska i prioritety deystviya [Mortality in Russia: main risk groups and priorities of action]. Nauchnyye doklady Moskovskogo Tsentra Karnegi [Scientific reports of the Carnegie Moscow Center]. Vyp.19: 83.

WHO (2006). Travmatizm i nasilie v Evrope. V chem vazhnost' etoj problemy i chto mozhno sdelat'. Rezjume [Injuries and violence in Europe. Why they matter and what can be done. Summary] (2006).WHO: 26. URL:

http://www.euro.who.int/_data/assets/pdf_file/0008/98405/E87321R.pdf (data accessed 09.10.2014).

World Health Organization European Detailed Mortality Database (WHO DMDB) (2014). URL: http://www.euro.who.int/en/data-and-evidence/databases/european-detailed-mortalitydatabase-dmdb2 (дата обращения: 09.10.2014).

World Health Organization European Health for all database (WHO HFA-DB) (2014). URL:http://data.euro.who.int/hfadb/ (дата обращения: 09.10.2014).

World Health Organization Mortality DataBase (WHO MDB) (2014). URL: http://www.who.int/healthinfo/statistics/mortality_rawdata/en/index.html (дата обращения: 09.10.2014). 